American Journal of Biological and Environmental Statistics
2017;3(4): $65-80$
http://www.sciencepublishinggroup.com/j/ajbes
doi: $10.11648 /$ j.ajbes.20170304.14
ISSN: 2471-9765 (Print); ISSN: 2471-979X (Online)

\title{
Effect of Exclosure Age on Carbon Sequestration Potential of Restorations in Tigray Region, N. Ethiopia
}

\author{
Samson Shimelse ${ }^{1,2, *}$, Tamrat Bekele ${ }^{1}$, Sileshi Nemomissa ${ }^{1}$ \\ ${ }^{1}$ Department of Plant Biology and Biodiversity Management, College of Natural and Computational Sciences, Addis Ababa University, \\ Addis Ababa, Ethiopia \\ ${ }^{2}$ College of Dryland Agriculture and Natural Resources, Mekelle University, Mekelle, Ethiopia
}

\section{Email address:}

samshimelse@yahoo.com (S. Shimelse), tambek07@yahoo.com (T. Bekele), snemomissa@gmail.com (S. Nemomissa)

${ }^{*}$ Corresponding author

\section{To cite this article:}

Samson Shimelse, Tamrat Bekele, Sileshi Nemomissa. Effect of Exclosure Age on Carbon Sequestration Potential of Restorations in Tigray Region, N. Ethiopia. American Journal of Biological and Environmental Statistics. Vol. 3, No. 4, 2017, pp. 65-80.

doi: 10.11648/j.ajbes.20170304.14

Received: November 23, 2017; Accepted: December 11, 2017; Published: January 8, 2018

\begin{abstract}
Conversion of degraded free grazing lands into exclosures is one option to promote natural regeneration of plants and to restore degraded ecosystems in Ethiopia. The present study investigated the change in ecosystem carbon stocks (ECS) and the enhancement of plant species richness and diversity following the establishment of exclosures on free grazing lands in Tigray, Ethiopia. Exclosures of 10, 15, and 20 years old were selected and each exclosure was paired with an adjacent free grazing land. A total of 120 quadrants were sampled using a stratified preferential sampling design technique with flexible systematic model. The differences in carbon stocks and vegetation composition between an exclosure and free grazing lands were assessed using a paired t-test. Data analyses also included descriptive statistics, inferential statistics using one way ANOVA, t-test and Chi-square test. All exclosures displayed higher ECS, and plant species richness, diversity and aboveground standing biomass than the free grazing lands. Differences in ECS between exclosures and free grazing lands varied between 32.96 and $61.0 \mathrm{t}^{\text {. ha }}{ }^{-1}$ increasing with exclosure age. Over a period of 20 years, the carbon dioxide sequestered in the investigated exclosures was $223.88 \mathrm{t}^{-\mathrm{ha}^{-1}}$. Differences in plant species richness and aboveground standing biomass between exclosures and free grazing lands also increased with exclosure age. The results of the present study confirm that establishment of exclosures on degraded free grazing lands in the Northern Highlands of Ethiopian is a viable option to restore ECS. The study showed that ECS in exclosures, in free grazing lands and the change in ECS following the establishment of exclosures on free grazing lands can be predicted using easily measurable biophysical and management-related indicators. Such information is necessary for the establishment of baseline information for carbon sequestration projects, for evaluation of whether exclosure establishment should be expanded, and for policymakers to take into account the value of exclosures in their management decisions. Although the study showed that exclosures are effective to restore ECS, expansion of exclosures would increase grazing pressure on the remaining free grazing area. Therefore, the decision to establish additional exclosures should also include an economical analysis and an evaluation of the social consequences of such a decision.
\end{abstract}

Keywords: Ecosystem Carbon Stock (ECS), Exclosure, Free Grazing Land, Northern Highlands of Ethiopia (Tigray)

\section{Introduction}

Land degradation refers to worsening of land resources [1] and hence decreasing of the sustainable productive capacity of agricultural lands in the world [2]. Particularly land degradation is a severe problem across sub-Saharan Africa, and Ethiopia is among the most affected countries in this respect. Deforestation (37\%), overgrazing (35\%), inappropriate agricultural practices such as over-cultivation, fertilization and nutrient depletion (28\%) and industrialization $(1 \%)$ are major human-caused factors of land degradation in the world [3]. Rangeland degradation is a widespread problem throughout sub-Saharan Africa and its restoration is a challenge for the management of many semiarid areas [4]. Land degradation affects livelihoods of the 
rural population depending on agricultural land resources especially in developing countries, and thus is a cause of poverty [5]. Land degradation in Ethiopia is triggered by population expansion and over-exploitation of the natural resources and is a major threat to sustainable land uses [6].

Tigray, in northern Ethiopia, is a region, which has fallen victim to the land degradation problem. It is a severely degraded region which can be typically characterized by heavily eroded and nutrient deficient soils, hydrological instability, reduced primary productivity and loss of biological diversity [7]. In response to the land degradation, the government of Ethiopia has initiated a number of projects including soil and water conservation works and the establishment of area exclosures [3]. REST [8] reported that the problem of land degradation in the semi-arid Tigray region is addressed based on the succession model, in that in some free areas livestock is completely excluded for an extended number of years.

Exclosures are a type of land management, implemented on degraded lands for environmental restoration [9]. Area exclosure in the Ethiopian context can be defined as the degraded land that has been excluded from human and livestock interference to enhance rehabilitation [3]. Establishment of area closures has been an important strategy for the rehabilitation of degraded hillsides. This practice has become very common, especially in the highlands of Ethiopia, due to the impressive improvement of productivity and reduction in soil erosion in the areas exclosed in the early 1980s [10].

Exclosures established in the semi-arid region of northern Ethiopia are effective in restoring species composition, diversity, biomass and key woody structural attributes of degraded free grazing lands, factors that normally lead to improved ecosystem function and health [4]. Exclosures have the potential to reduce water erosion [11]. Exclosure is a cheap and fast mechanism for rehabilitating degraded lands [7].

Trees are important sinks for atmospheric carbon i.e. carbon dioxide since $50 \%$ of their standing biomass is carbon itself [12]. Importance of forested areas in carbon sequestration is already accepted, and well documented in developed nations [13]. However, hardly any attempt has been made to study the potential of trees in carbon sequestration in developing countries. Therefore, this research project focused on the analyses of the effects of the conversion of free grazing lands to exclosures on ecosystem carbon sequestration as well as to investigate the effect of age since exclosure on ecosystem carbon stocks and ecosystem services.

\section{Material and Methods}

\subsection{Study Area}

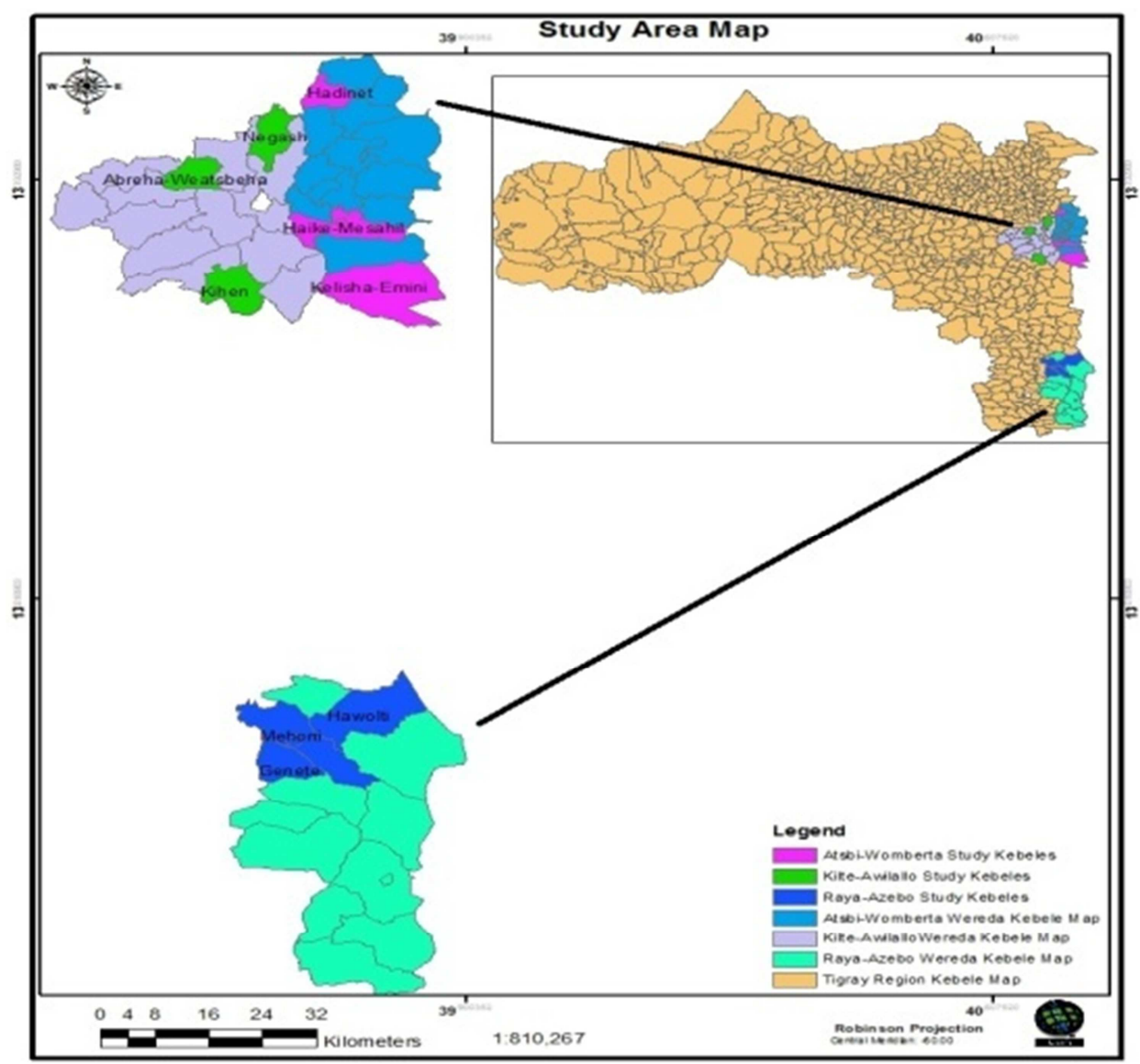

Figure 1. Map of Selected Kebeles of the Study areas. 
Tigray Region has five administrative zones, which are further sub-divided into 35 Woredas (districts). The study was conducted in three Woredas/districts of Tigray $\left(12^{\circ}-15^{\circ}\right.$ $\mathrm{N}$ latitude and $36^{\circ} 30^{\prime}-40^{\circ} 30^{\prime} \mathrm{E}$ longitude), the northernmost region of Ethiopia (Figure 1). In the study area, the first exclosures were established almost three decades ago and accordingly able to select replicated $(n=3)$ exclosures of 10,15 and 20 years old. Separate adjacent free grazing lands, i.e. a control for each exclosure were selected. The area of the selected exclosures ranged from 8 to 125 ha whereas that of the adjacent free grazing lands ranged from 2 to 45 ha.

The specific study area was selected based on criteria's from the list of districts of the region that have had greater than twenty-five years age area exclosures with different management and utilization system. The wide variety of altitude (range between 1400 and 2900), the age of exclosures (between 1 and 25 years), size of exclosures (from 8 to 125 hectares), proportion of exclosure, and distance from residence (varying in the range 0.5 to 9 kilometers). Fair accessibility is also under consideration. However, it is rare to find all the exclosures in a relatively homogenous environment, mainly, agro-ecological zone.

\subsection{Geology and Soils}

Soils of the Atsbi Wemberta and Kilte Awelaelo sites were classified into four major groups: Luvisols (Alfisols), Regosols (Entisols), Cambisols (Inceptisols) and Calcisols (Aridisols) [14]. The Fluvisols are mainly confined to the alluvial deposits along the river valley [15]. A large part of the vegetation in the area is formed on Enticho sandstone and Crystalline Basement [16] In Raya Azebo the dominant soil types are Leptosols, Cambisols, Vertisols, Regosols, and Arenosols [17]. Large parts of the undulating terrains in northern Ethiopia are characterized by shallow soils and frequent rock outcrops, while relatively thick soils are found along valley bottoms.

\subsection{Topography}

The topography of the areas comprises several forms from high slope to flat, ragged and deep gorges and gullies. Most of the areas were characterized by cleared forest and considered as the most degraded and eroded area in the past. The topography of Tigray contains the three main traditional climatic divisions of Ethiopia: the Kolla - lowlands (c14001800 meters above sea level) with relatively low rainfall and high temperatures; the Woina dega - middle highlands (c1800-2400 m. a. s. 1.) with medium rainfall and medium temperatures; Dega - highlands (c2400-3400 m. a. s. 1.) with somewhat higher rainfall and cooler temperatures [73].

\subsection{Climate}

Analysis of the meteorological data showed that the mean annual temperature for Raya Azebo was $20.8^{\circ} \mathrm{C}$ and the mean minimum and maximum were 11.8 and $33.5^{\circ} \mathrm{C}$ respectively. The hottest months are April and June, while it is cold from
September to December. The mean annual rainfall is 604 $\mathrm{mm}$, which varied greatly from year to year. Generally, the study area has bimodal rainfall pattern, with low rainfall from February to May and the main rainy season (June September). Kilite Awulaelo Woreda average daily air temperature of the area ranges between $8^{\circ} \mathrm{C}$ and $30.1^{\circ} \mathrm{C}$ with a mean of $19.7^{\circ} \mathrm{C}$. The mean annual rainfall of the area is about $610 \mathrm{~mm}$. Kilite Awulaelo Woreda has unimodal rainfall pattern (Figure 2).
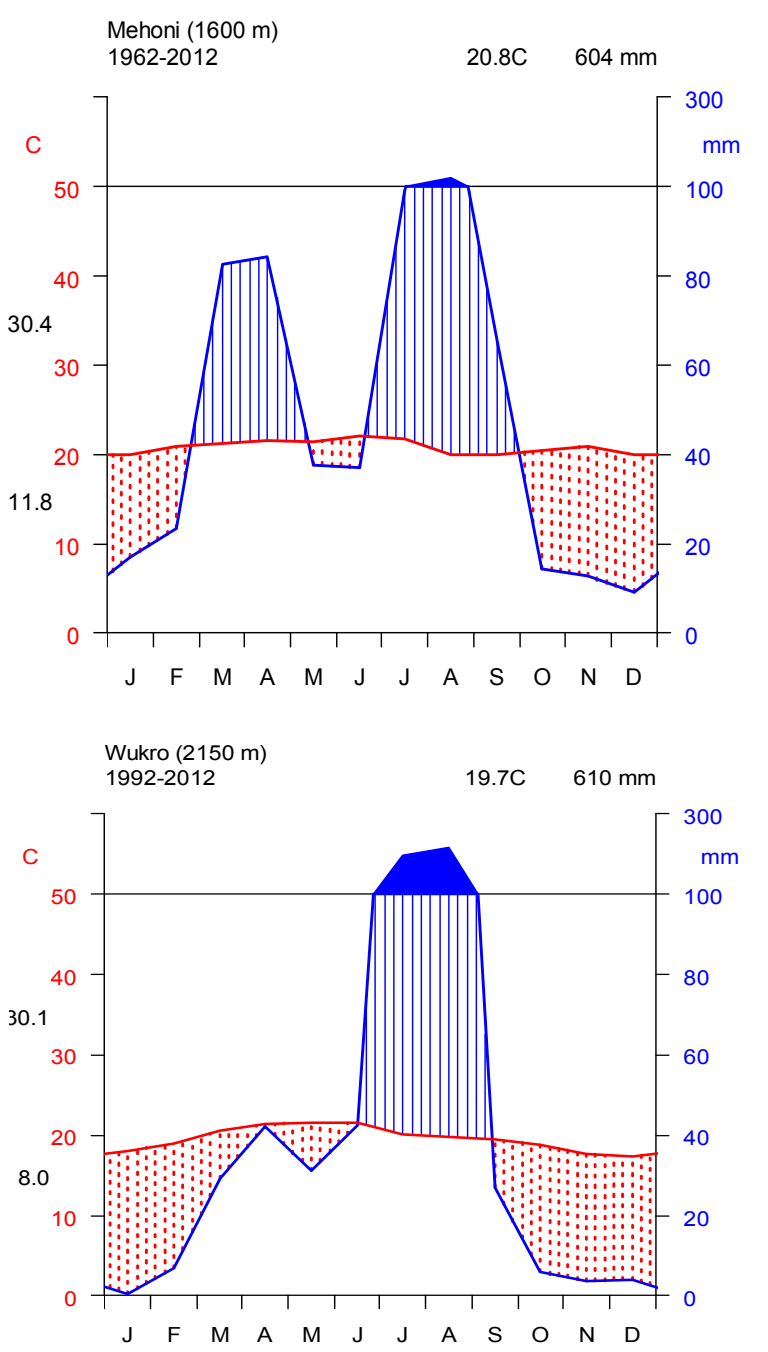

Figure 2. Climatic diagram.

\subsection{Vegetation}

The most common woody vegetation species in exclosures and in adjacent grazing lands included Acacia etbaica, Acacia seyal, Becium grandiflorum, Euclea racemosa subsp. schimperi and Maytenus senegalensis. Understorey vegetation of exclosures and free grazing lands were dominated by grass species such as Hyparrhenia hirta and Digitaria ternata.

\subsection{Sampling Design}

In this study, space-for-time substitution were used [18]. 
The inherent assumption of such a study is that the exclosures and adjacent free grazing lands had similar conditions before the establishment of the exclosures. Therefore, selected separate adjacent free grazing lands for each exclosure to minimize differences in inherent soil properties. Furthermore, soil and terrain conditions between the exclosures and the adjacent grazing land sites were as similar as possible.

A combination of approaches was taken to obtain data, including satellite images, aerial photographs, historical records and ground-based surveys. This was used to predict the changes in the vegetation cover over time and to assess the current status of restoration on the exclosures. In addition to the secondary data from Woreda agriculture office restored vegetation areas were estimated based on analysis of satellite imagery and include both natural and plantation vegetations.

\subsection{Floristic Study}

After reconnaissance survey, data collection was made from July to October 2015. A stratified preferential sampling design technique with flexible systematic model was used for data collection. Flexible systematic model is a special technique based on the principle of optimum allocation of samples [19]. This method may be viewed as a special form of stratified sampling since samples are allocated on the basis of some predetermined criteria [20]. Local variation of floristic diversity with restoration age was used as a major criterion for sampling. The study area was first divided up into three agroecological zones based on altitude before samples were chosen on the basis of size and variation in the landscape. To take representative samples, 30 quadrants have been selected from each age class. In each restoration age classes, sampling was carried out based on the size and local diversity of vegetation cover. In restorations where different size, diversity, and rate of change of vegetation cover was higher more samples were taken whereas in areas with small size and little change in vegetation heterogeneity a small number of sample plots were laid out. Within each site, 3-4 quadrants were taken from the central portions of the restoration and at least $20 \mathrm{~m}$ away from the edge. The sampling sites were positioned at different aspects and from different slopes. Generally, the quadrants for sampling were selected in such a manner that each is a representative of the vegetation of which it is part and that each plot sampled therein yields a more or less typical description of that vegetation in terms of both floristic composition and structure.

Data on vegetation and environmental parameters were gathered from 120 quadrants $(90$ from restorations or exclosures of different ages and 30 from adjacent free grazing lands), The quadrants were $20 \mathrm{~m}$ x $20 \mathrm{~m}\left(400 \mathrm{~m}^{2}\right)$ in size [20]. All vascular plant species were recorded and collected. To produce species diversity/richness of the study area, species occurring outside of the quadrants, but inside the exclosures were also recorded only as 'present', but they were not used in the subsequent data analysis. Species richness and the presence or absence of herbaceous plants were recorded in a $2 \mathrm{~m} \mathrm{x} 2 \mathrm{~m}\left(4 \mathrm{~m}^{2}\right)$ subplot inside each main quadrant from five points, one at each corner and one at the center as used by Getinet M. [21]. Cover/abundance (ground cover) for each plant species was estimated following the procedure of Braun-Blanquet [20], to determine the plant community types. The percent cover values, which are visually estimated in the field, were later converted into a modified 1-9 Braun-Blanquet scale [22]. During data collection period, plant specimens were collected, pressed, dried properly and brought to the National Herbarium (ETH), Addis Ababa University for identification and verification Plant nomenclature followed Flora of Ethiopia and Eritrea.

\subsection{Soil Data}

Soil samples were collected from 120 quadrants for soil analysis. From each quadrant, five soil samples (from a depth of $20 \mathrm{~cm}$ ) were collected from an area of $2 \mathrm{~m} \times 2 \mathrm{~m}$ from each corner and center and mixed to produce a composite soil sample, each weighing about $0.7-1 \mathrm{~kg}$. One core sample was taken for bulk density analysis. The soil samples were air dried by spreading on plastic trays, crushed and sieved with a mesh size of $2 \mathrm{~mm}$. Soil organic carbon, bulk density, and particle size were determined using the Walkley-Black method [23], the core method [24] and the hydrometer method [25] respectively.

\subsection{Carbon Stock Estimation}

To estimate the above-ground biomass of the trees different mathematical allometric equations have been developed and used by many researchers. The equations are different depending on the type of species, geographical locations, forest stand types, climate and others [26]. From the environmental point of view, cost of estimation and time required, it is not possible to cut the trees to estimate their biomass. Thus, equations developed by Woody Biomass Inventory and Strategic Planning Project [27] for woody species in Ethiopia were used based on species-specific allometric equations (Table 8). For those species that are not in the list general model for all woody species in Moist Kolla agro-ecological zone of Ethiopia (Equation 1) were used for estimating tree carbon stock.

The following equation was used:

$$
\mathrm{AGB}=(1.4277 * \mathrm{DSH})+(0.0088 *(\mathrm{DSH} \exp 3.0))
$$

Where, AGB = Above-ground Biomass (kg/tree) andDSH $=$ Diameter at Stump Height $(\mathrm{cm})$

The overall carbon stocks (carbon density) of a given forest obtained from adding all the carbon stocks in different carbon pools together can be extrapolated into a hectare. The dry biomass obtained by using allometric equations can be converted into carbon except for soil, which usually measures carbon directly. Carbon is $50 \%$ of the dry biomass of an individual tree $[28 ; 29 ; 30 ; 31]$.

\subsection{Carbon Stock Analysis}

\subsubsection{Aboveground Biomass}

The equation developed by Woody Biomass Inventory and 
Strategic Planning Project [27] for woody species in Ethiopia was used to estimate the AGB of the vegetation which relates only DSH. Since the area is not a forest and the vegetation is at the early stage of succession other measurements like DBH will not be effective as DSH to implement other models developed based on DBH and Height.

\subsubsection{Herbaceous Biomass}

All herbaceous and other nonwoody plants were harvested or cut into pieces and the fresh weight was collected from a 4 $\mathrm{m}^{2}$ area following the same procedure like for the soil samples.

\subsubsection{Belowground Biomass}

Since direct measurement of BGB is an expensive and time-consuming task, it is derived from AGB (shoot-root ratio). The $\mathrm{BGB}$ is $20 \%$ of $\mathrm{AGB}$ (Equation 2) [30]

$$
\mathrm{BGB}=0.2 * \mathrm{AGB}
$$

$$
\operatorname{SOC}\left(\mathrm{tC} \mathrm{ha}{ }^{-1}\right)=(\% \mathrm{C} / 100) \times \mathrm{BD}\left(\mathrm{Mgm}^{-3}\right) \times \mathrm{D}(\mathrm{m}) \times 10000 \mathrm{~m}^{2} \mathrm{ha}^{-1}
$$

Where, $\mathrm{SOC}=$ soil organic carbon, $\mathrm{BD}=$ soil bulk density, $\mathrm{D}=$ the total depth at which the sample was taken $(20 \mathrm{~cm})$, and $\% \mathrm{C}=$ carbon concentration $(\%)$ determined in the laboratory.

\subsubsection{Total Carbon Stock}

Since the area is not a forest and the vegetation is at the early stage of succession the carbon pool in the litter and dead wood is insignificant. There is hardly any appreciable amount of litter and dead wood prsent in the study area. Therefore, the total carbon stocks (carbon density) were calculated by summing up all the carbon stocks of each carbon pool of the vegetation (Equation 4) [29]. The total carbon stock was then converted to tons of $\mathrm{CO}_{2}$ equivalent by multiplying it by $44 / 12$, or 3.67 of the Molecular weight ratio of $\mathrm{CO}_{2}$ to $\mathrm{O}_{2}$ [29]. Carbon stock density of the study area could be calculated as:

$$
\mathrm{C} \text { density }=\mathrm{AGC}+\mathrm{BGC}+\mathrm{HBC}+\mathrm{SOC}
$$

Where: $\mathrm{C}$ density $=$ the summed carbon stocks in all carbon pools $\left(\mathrm{t} \mathrm{ha}^{-1}\right), \mathrm{AGC}=$ aboveground vegetation carbon $\left(\mathrm{t} \mathrm{ha}^{-1}\right), \mathrm{BGC}=$ belowground carbon $\left(\mathrm{t} \mathrm{ha}^{-1}\right), \mathrm{HBC}=$ herbaceous biomass carbon $\left(\mathrm{t} \mathrm{ha}^{-1}\right)$ and $\mathrm{SOC}=$ Soil organic carbon $\left(\mathrm{t} \mathrm{ha}^{-1}\right)$.

In order to understand climate change mitigation potential
Where: BGB-belowground biomass, AGB-aboveground biomass

\subsubsection{Soil Organic Carbon}

For convenience and cost-efficiency, it is advised to sample to a constant depth in the soil, maintaining a constant sample volume rather than mass [32]. It can be collected systematically within $4 \mathrm{~m}^{2}$ quadrants nested in the main plots for determination of carbon stock [28]. Soil bulk density is necessary to calculate soil organic carbon. In this study, it was calculated as follows [29] [32]:

$$
\text { Soil bulk density }\left(\mathrm{g} \mathrm{cm}^{-3}\right)=\frac{\text { oven-drysamplemass }(\mathrm{g})}{\text { Samplevolume }\left(\mathrm{cm}^{3}\right)}
$$

The carbon stock of SOC was estimated by the equation: of the study area data on trees, shrubs, herbaceous and soil carbon were processed using MS Excel spreadsheet and SPSS software package of one-way analyses of variance (ANOVA).

\section{Results and Discussion}

\subsection{Vegetation Composition in Exclosures and Free Grazing Lands}

A total of 142 plant species belonging to 118 genera and 52 families were identified (Table 7). About four major life forms were identified of which $61(42.96 \%)$ of the species were herbs, $50(35.21 \%)$ were shrubs, $29(20.42 \%)$ were trees and the remaining $2(1.41 \%)$ were climbers. The four plant families with the highest percentages of the total recorded were Fabaceae 23 (16.2\%), Poaceae 22 (15.49\%), Asteraceae 12 (8.45\%) and Acanthaceae 8 (5.63\%). About $40.38 \%$ of the families were represented by more than one species and $59.62 \%$ of the families were represented by single species each accounting to $0.70 \%$ of the total (Table 7 ).

The oldest exclosures displayed a higher number of plant families that are represented by two or more species. In all

\begin{tabular}{|c|c|c|c|c|c|c|c|c|c|}
\hline & Free grazing & Richness & $\mathbf{H}$ & Evenness & $\begin{array}{l}\text { Above-ground } \\
\text { biomass }\left(\mathrm{t} \mathrm{ha}^{-1}\right)\end{array}$ & $\begin{array}{l}\text { Herb+C. Sp. } \\
\text { in no. }\end{array}$ & S. sp. in no. & $\begin{array}{l}\text { T. sp. in } \\
\text { no. }\end{array}$ & $\begin{array}{l}\text { Eco. Imp. } \\
\mathrm{S}+\mathrm{T}\end{array}$ \\
\hline & & 76 & 2.79 & 0.87 & 1.62 & 51 & 14 & 11 & 16 \\
\hline \multirow{3}{*}{ Exclosure } & $10 \mathrm{Yr}$ & 87 & 3.52 & 0.81 & 4.73 & 42 & 27 & 18 & 29 \\
\hline & $15 \mathrm{Yr}$ & 91 & 3.68 & 0.82 & 9.72 & 39 & 29 & 23 & 34 \\
\hline & $20 \mathrm{Yr}$ & 103 & 3.82 & 0.84 & 13.93 & 44 & 31 & 28 & 41 \\
\hline$P$ value & & .001 & .150 & .093 & .129 & .014 & .001 & .001 & .001 \\
\hline Sig. Codes & & $* * *$ & & 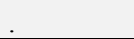 & & $*$ & $* * *$ & $* * *$ & $* * *$ \\
\hline
\end{tabular}
exclosures, Fabaceae, Poaceae, and Asteraceae families contributed the highest number of plant species.

Table 1. Plant species richness, diversity, aboveground standing biomass, and herbaceous, shrub and tree species in exclosures and free grazing lands.

*the $p$-values are values obtained after paired t-test @ 95\% CI or.05 significance level.

Sig. codes: 0 ‘***’ 0.001 '**’ 0.01 '*’ 0.05 '.' 0.1 ' ’ 1 .

H- Diversity, S- shrub, T- tree, C- Climber, Eco. Imp- Economically important. 
Exclosures displayed a higher number of shrub and tree species compared to the adjacent free grazing lands (Table 1). Moreover, the number of species also increased with exclosure age. Furthermore, a higher number of economically important indigenous shrub and tree species (i.e., shrub and tree species that can be used by the local communities as sources of fuelwood and construction materials) were recoreded in exclosures compared to the adjacent free grazing lands. The proportion of economically important shrub and tree species recorded were considerable.

\subsection{Changes in Aboveground Biomass, Species Richness, and Diversity in Relation to Exclosure Age}

The higher plant species richness, diversity and aboveground standing biomass in all exclosures compared to the grazing lands (Table 1) illustrates that rehabilitation of the degraded grazing lands occurs in relatively short periods of time after restricting human and livestock interference. Other case studies conducted in the central and northern highlands of Ethiopia have also shown that exclosures can be effective in improving aboveground biomass, density, composition and diversity of plant species that are naturally regenerated through providing favorable microhabitats to plants [7]; [11]. In semi-arid Kenya, Verdoodt et al., [33] and Muchiru et al., [34], and in Iran, Hosseinzadeh et al., [35] reported that exclosures increased woody and herbaceous species richness, diversity and aboveground biomass.

The richness of plant species and aboveground biomass increased with exclosure age. This was supported by the decreasing trend of vegetation similarity between exclosures and grazing lands with exclosure age and by the increase in species turnover (or differences in species richness between exclosures and grazing lands) with exclosure age (i.e., the increase in beta diversity; Table 1). The strong increase in plant species richness during the first 10 years following exclosure establishment (Table 1) is the result of the establishment of large numbers of herbaceous and small shrub species as a result of the prohibition of grass and herbaceous species harvesting. The lower increase in plant species richness from 15 years to 20 years of exclosure establishment was probably a manifestation of large shrub and tree species which gain dominance and suppress the abundance of herbaceous, grasses and small shrub species through canopy closure. This was supported by the consistent increase in the number of tree species with exclosure age and the higher number of shrub species in the oldest exclosures. The substantial increase in aboveground biomass with exclosure age is a reflection of vegetation succession illustrated by the increase in abundance and biomass of large shrubs and trees. The increasing proportion of species of the Fabaceae family which are legumes in the oldest exclosures probably improved nitrogen availability with exclosure age thereby contributing to the continuing biomass increase [36]. Similar successional patterns showing that herbaceous/grass biomass and diversity decrease while shrub and tree abundance increase with exclosure age have been reported in other case studies conducted in the highlands and lowlands of Ethiopia [4; 37] and in South African savanna areas [38].

\subsection{Ecosystem Carbon Stocks in Exclosures and Free Grazing Lands}

Exclosures showed higher soil carbon concentration, soil carbon stocks, and aboveground carbon stocks than the adjacent free grazing lands (Table 2). The difference between exclosures and free grazing lands in soil carbon stock, at each exclosure age, ranged from 30.6 to 51.5 ton $\mathrm{C} \mathrm{ha}^{-1}$ whereas the aboveground carbon stock varied between 2.4 and $9.5 \mathrm{t} \mathrm{C}$ ha $^{-1}$. These values translated to soil carbon stock increase of 22.1 to $40.6 \%$ and to aboveground carbon stock increase of 40.7 to $74.7 \%$ following conversion of degraded grazing lands to exclosures within 10 to 20 years. Soil carbon stock contributed most of the increase in ECS compared to aboveground carbon in exclosures (Table 2). Woody biomass carbon consistently increased with exclosure age while grass biomass carbon slightly decreased (Table 2). The influence of exclosure age on ECS was linear with time as the increase in exclosure age and it was significant between free grazing and exclosures as well within each age variable exclosures. The minimum and maximum carbon stock was 32.96 and 61.0 tha $^{-1}$, in free grazing and 20 years exclosure, respectively (Table 2).

Table 2. Mean biomass and carbon stock of different carbon pools and $\mathrm{CO}_{2}$ equiv. of free grazing and different ages of exclosures.

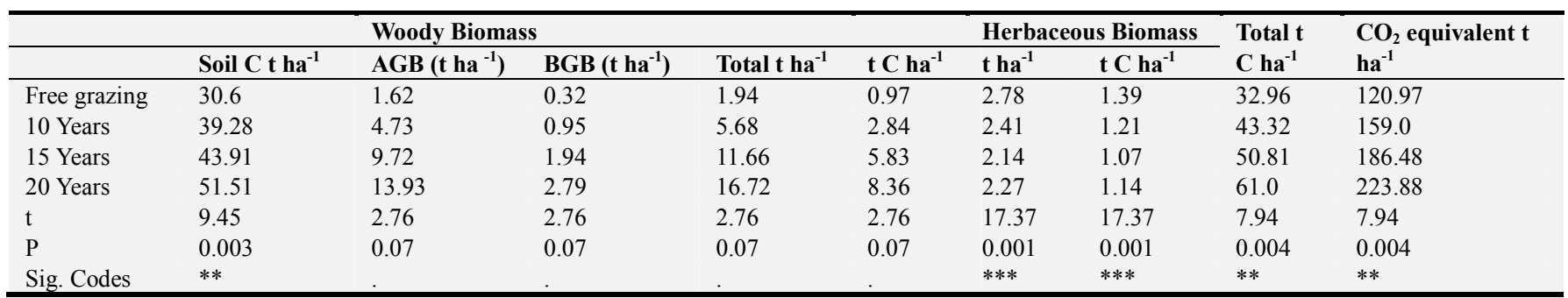

Sig. codes: 0 ‘*** 0.001 '**’ 0.01 '*’ 0.05 ‘’ 0.1 ' ' 1 .

As could beseen from Table 3, in exclosures, the largest carbon stock was observed in Acacia saligna (21.6 kg/single sp). Euphorbia abyssinica, Faidherbia albida, and Capparis tomentosa also showed high carbon stock than the rest of the species recorded in the forest $(13.65 \mathrm{~kg} /$ single $\mathrm{sp}, 11.66 \mathrm{~kg} /$ single $\mathrm{sp}$. and $8.32 \mathrm{~kg} /$ single $\mathrm{sp}$.), respectively. The least above-ground carbon stock was recorded for Delonix regia, Rhamnus prinoides, Myrsine africana and Rhus glutinosawith a value of less or 
equal to $2.1 \mathrm{~kg} / \mathrm{single}$ species for each. The minimum and maximum carbon stock per species was 2.04 and $21.6 \mathrm{~kg}$ recorded for Delonix regia and Acacia saligna respectively (Table 3).

Table 3. Mean $A G B$ and BGB/sp., Carbon stock/total sp., carbon/single sp., $\mathrm{CO}_{2}$ equ./total sp. and $\mathrm{CO}_{2}$ equ. per single sp. of selected species recorded from exclosures.

\begin{tabular}{|c|c|c|c|c|c|c|c|c|}
\hline Species & Life form & $\begin{array}{l}\text { AGB } \\
{\left.\text { (ton } \text { ha }^{-1}\right)}\end{array}$ & $\begin{array}{l}\text { BGB } \\
\left(\text { ton ha }{ }^{-1}\right)\end{array}$ & TB & $\begin{array}{l}\text { C } \\
\text { (ton/total Sp.) }\end{array}$ & $\begin{array}{l}\text { C } \\
\text { (kg/ single Sp.) }\end{array}$ & $\begin{array}{l}\mathrm{CO}_{2} \text { equ } \\
\text { (ton/total Sp) }\end{array}$ & $\begin{array}{l}\mathrm{CO}_{2} \text { equ } \\
(\mathrm{kg} / \text { single } \mathrm{Sp})\end{array}$ \\
\hline Astragalus atropilosulus & Shrub & 129.97 & 25.99 & 155.96 & 77.98 & 6.68 & 286.19 & 24.53 \\
\hline Euphorbia abyssinica & Tree & 54.98 & 11.00 & 65.98 & 32.99 & 13.65 & 121.06 & 50.10 \\
\hline Acacia asak & Shrub & 38.37 & 7.67 & 46.04 & 23.02 & 5.68 & 84.48 & 20.83 \\
\hline Cordia africana & Tree & 32.03 & 6.41 & 38.44 & 19.22 & 3.05 & 70.53 & 11.19 \\
\hline Cupressus lusitanica & Tree & 31.27 & 6.25 & 37.52 & 18.76 & 4.00 & 68.85 & 14.67 \\
\hline Acacia saligna & Tree & 27.00 & 5.40 & 32.40 & 16.20 & 21.60 & 59.45 & 79.27 \\
\hline Faidherbia albida & Tree & 24.29 & 4.86 & 29.15 & 14.57 & 11.66 & 53.48 & 42.78 \\
\hline Acacia decurrens & Tree & 24.08 & 4.82 & 28.90 & 14.45 & 4.45 & 53.03 & 16.32 \\
\hline Dovyalis verrucosa & Shrub & 18.08 & 3.62 & 21.70 & 10.85 & 2.52 & 39.82 & 9.25 \\
\hline Colutea abyssinica & Shrub & 16.36 & 3.27 & 19.64 & 9.82 & 2.58 & 36.03 & 9.47 \\
\hline Chamaecrista hochstetteri & Shrub & 14.65 & 2.93 & 17.58 & 8.79 & 4.06 & 32.25 & 14.89 \\
\hline Capparis tomentosa & Shrub & 11.94 & 2.39 & 14.32 & 7.16 & 8.32 & 26.28 & 30.52 \\
\hline Rosa abyssinica & Shrub & 9.60 & 1.92 & 11.52 & 5.76 & 2.16 & 21.14 & 7.93 \\
\hline Boscia angustifolia & Tree & 8.15 & 1.63 & 9.77 & 4.89 & 3.26 & 17.94 & 11.96 \\
\hline Dovyalis abyssinica & Shrub & 5.13 & 1.03 & 6.16 & 3.08 & 2.64 & 11.30 & 9.69 \\
\hline Calpurinia aurea & Shrub & 3.91 & 0.78 & 4.69 & 2.34 & 3.25 & 8.60 & 11.91 \\
\hline Eucalyptus globulus & Tree & 3.50 & 0.70 & 4.19 & 2.10 & 3.43 & 7.70 & 12.60 \\
\hline Tephrosia interrupta & Shrub & 0.13 & 0.03 & 0.15 & 0.08 & 2.70 & 0.28 & 9.91 \\
\hline Indigofera arrecta. & Shrub & 0.12 & 0.02 & 0.14 & 0.07 & 2.58 & 0.26 & 9.47 \\
\hline Opuntia ficus-indica & Shrub & 0.11 & 0.02 & 0.14 & 0.07 & 2.46 & 0.25 & 9.03 \\
\hline Rumex nervosus & Shrub & 0.11 & 0.02 & 0.13 & 0.07 & 2.35 & 0.24 & 8.63 \\
\hline Osyris quadripartita & Shrub & 0.11 & 0.02 & 0.13 & 0.07 & 2.34 & 0.24 & 8.59 \\
\hline Grewia $s p$. & Shrub & 0.10 & 0.02 & 0.12 & 0.06 & 2.18 & 0.22 & 7.99 \\
\hline Myrsine africana & Shrub & 0.10 & 0.02 & 0.12 & 0.06 & 2.10 & 0.21 & 7.71 \\
\hline Rhus glutinosa & Tree & 0.10 & 0.02 & 0.12 & 0.06 & 2.10 & 0.21 & 7.71 \\
\hline Rhamnus prinoides & Shrub & 0.10 & 0.02 & 0.12 & 0.06 & 2.09 & 0.21 & 7.68 \\
\hline
\end{tabular}

In free grazing area, the largest carbon stock was observed in Eucalyptus camaldulensis ( $7.9 \mathrm{~kg} / \mathrm{single} \mathrm{sp).} \mathrm{Acacia} \mathrm{etbaica,}$ Vernonia amygdalina, Euclea schimperi and Rhus natalensisalso showed high carbon stock than the rest of the species recorded in the forest $(5.08 \mathrm{~kg} /$ single sp, 4.89 ton/single sp., 4.22 and $4.19 \mathrm{~kg} /$ single sp.), respectively. The least above-ground carbon stock was recorded for Schinus mollewith a value of $1.03 \mathrm{~kg} /$ single species (Table 4).

Table 4.1 Mean AGB and BGB/Sp., Carbon stock/total sp., carbon/single sp., $\mathrm{CO}_{2}$ equ/total sp and $\mathrm{CO}_{2}$ equ per single sp. of selected species recorded from free grazing areas.

\begin{tabular}{|c|c|c|c|c|c|c|c|c|}
\hline Species & $\begin{array}{l}\text { Life } \\
\text { form }\end{array}$ & $\begin{array}{l}\text { AGB (ton } \\
\mathrm{ha}^{-1} \text { ) }\end{array}$ & $\begin{array}{l}\text { BGB (ton } \\
\text { ha }^{-1} \text { ) }\end{array}$ & $\begin{array}{l}\text { TB (ton } \\
\left.\mathrm{ha}^{-1}\right)\end{array}$ & $\begin{array}{l}\mathrm{C}(\text { ton/total } \\
\text { tree }\end{array}$ & $\begin{array}{l}\mathrm{C}(\mathrm{Kg} / \text { single } \\
\text { tree) }\end{array}$ & $\begin{array}{l}\mathrm{CO}_{2} \text { equ } \\
\text { (ton/total tree) }\end{array}$ & $\begin{array}{l}\mathrm{CO}_{2} \text { equ }(\mathrm{Kg} / \text { single } \\
\text { tree) }\end{array}$ \\
\hline Euphorbia abyssinica & Tree & 12.98 & 2.60 & 15.58 & 7.79 & 2.28 & 28.59 & 8.37 \\
\hline Acacia etbaica & Tree & 5.65 & 1.13 & 6.78 & 3.39 & 5.08 & 12.43 & 18.65 \\
\hline Stereospermum kunthianum & Tree & 3.87 & 0.77 & 4.64 & 2.32 & 3.48 & 8.51 & 12.77 \\
\hline Ricinus communis. & Shrub & 2.73 & 0.55 & 3.28 & 1.64 & 2.81 & 6.01 & 10.31 \\
\hline Eucalyptus camaldulensis & Tree & 2.20 & 0.44 & 2.63 & 1.32 & 7.90 & 4.83 & 29.00 \\
\hline Sageretia thea & Shrub & 2.13 & 0.43 & 2.56 & 1.28 & 2.56 & 4.69 & 9.38 \\
\hline Euclea schimperi & Shrub & 1.76 & 0.35 & 2.11 & 1.06 & 4.22 & 3.88 & 15.50 \\
\hline Laggera tomentosa & Shrub & 0.36 & 0.07 & 0.43 & 0.22 & 2.58 & 0.79 & 9.47 \\
\hline Cadia purpurea & Shrub & 0.34 & 0.07 & 0.41 & 0.20 & 2.44 & 0.75 & 8.96 \\
\hline Euclea racemosa subsp. schimperi & Shrub & 0.32 & 0.06 & 0.38 & 0.19 & 2.28 & 0.70 & 8.37 \\
\hline Acokanthera schimperi & Shrub & 0.29 & 0.06 & 0.35 & 0.18 & 2.10 & 0.64 & 7.71 \\
\hline Schinus molle & Tree & 0.14 & 0.03 & 0.17 & 0.09 & 1.03 & 0.31 & 3.77 \\
\hline
\end{tabular}

The mean carbon stock of the study area was $42.34 \pm 9.38 \mathrm{t} \mathrm{ha}^{-1}$ (Table 5). The minimum and maximum equivalent carbon dioxide of the study area was 120.97 and $223.88 \mathrm{t} /$ ha, and the mean is $155.39 \pm 34.42 \mathrm{tha}^{-1}$. The mean above-ground equivalent carbon dioxide for exclosures was $189.81 \mathrm{t} \mathrm{ha}^{-1}$. 
Table 5. Mean biomass and carbon stock of different carbon pools and $\mathrm{CO}_{2}$ equiv. of free grazing and exclosures.

\begin{tabular}{|c|c|c|c|c|c|c|c|c|c|c|c|}
\hline & \multicolumn{4}{|c|}{ Woody Biomass } & \multicolumn{2}{|c|}{ Herbacious Biomass } & \multirow[b]{2}{*}{$\begin{array}{l}\text { AGB C } \\
\left(t \text { ha }^{-1}\right)\end{array}$} & \multirow[b]{2}{*}{$\begin{array}{l}\text { BGB C } \\
\left(t \text { ha }^{-1}\right)\end{array}$} & \multirow[b]{2}{*}{$\begin{array}{l}\text { Soil C } \\
\left(t^{-1} a^{-1}\right)\end{array}$} & \multirow{2}{*}{$\begin{array}{l}\text { Total } \\
\left(\mathrm{t} \mathrm{C} \mathrm{ha}^{-1}\right)\end{array}$} & \multirow[b]{2}{*}{$\begin{array}{l}\mathrm{CO}_{2} \text { equ. } \\
\left(\mathrm{t} \mathrm{ha}^{-1}\right)\end{array}$} \\
\hline & $\begin{array}{l}\text { AGB } \\
\left(\mathrm{t} \mathrm{ha}^{-1}\right)\end{array}$ & $\begin{array}{l}\text { BGB (t } \\
\left.h^{-1}\right)\end{array}$ & $\begin{array}{l}\text { Total } \\
\left(\mathrm{t} \mathrm{ha}^{-1}\right)\end{array}$ & t C ha ${ }^{-1}$ & $\mathrm{tha}^{-1}$ & t C ha ${ }^{-1}$ & & & & & \\
\hline Free grazing & 1.62 & 0.32 & 1.94 & 0.97 & 2.78 & 1.39 & 2.20 & 0.16 & 30.60 & 32.96 & 120.97 \\
\hline Exclosures & 9.46 & 1.89 & 11.35 & 5.68 & 2.27 & 1.14 & 5.87 & 0.95 & 44.90 & 51.72 & 189.81 \\
\hline Mean & 5.54 & 1.11 & 6.65 & 3.33 & 2.53 & 1.27 & 4.04 & 0.56 & 37.75 & 42.34 & 155.39 \\
\hline Standard error & 3.92 & 0.79 & 4.71 & 2.36 & 0.26 & 0.13 & 1.84 & 0.40 & 7.15 & 9.38 & 34.42 \\
\hline
\end{tabular}

As pointed out earlier and from the inherent assumption of space-for-time substitution approach, the exclosures and free grazing lands had similar conditions before exclosure establishment. This assumption tested using variables measured in the exclosure and free grazing lands that are less dependent on land use (e.g., soil texture). There was no difference in soil texture between any of the exclosures and free grazing lands $(p>0.05)$. Significant differences were observed only for site characteristics that are dependent on land use. From these analyses, that in general, the sites were comparable and differences in soil and aboveground carbon stocks measured between the exclosures and free grazing lands were caused by land use change and not by inherent site variability.

\subsection{Variation of Soil and Aboveground Carbon Stocks in Exclosure and Free Grazing Lands}

An increase in vegetation cover (woody and herbaceous biomass) would not only increase litter input into the soil but would also reduce the erosive impact of raindrops, resulting in less soil erosion and consequently less soil carbon losses [11]. A similar mechanism was reported from a study of four different land uses in two ecological regions of Ethiopia, showing that soil organic matter concentration was influenced by the amount and type of vegetation and grasses as well as intensity of grazing [39]. The higher soil and vegetation carbon stocks in all exclosures indicate that exclosures have a significant positive effect on the restoration of ECS, even in highly degraded free grazing lands. Similar trends were reported from case studies conducted on exclosures in the central and northern highlands of Ethiopia: an increase in soil organic carbon of $22.6 \mathrm{t} \mathrm{C}$ ha-1 in the 0 $0.15-\mathrm{m}$ depth after 8 years of exclosure establishment (i.e. on average $2.8 \mathrm{t} \mathrm{C}$ ha-1 $\mathrm{yr}^{-1}$ ) [40], $75.0 \mathrm{t} \mathrm{C} \mathrm{ha}^{-1}$ increase in the 0$0.3-\mathrm{m}$ depth after 20 years (or $3.8 \mathrm{t} \mathrm{C} \mathrm{ha}^{-1} \mathrm{yr}^{-1}$ ) [41], and 31.3 $\mathrm{t} C$ ha- 1 increase in the $0-0.15-\mathrm{m}$ depth after 20 years (or 1.5 t $\mathrm{C} \mathrm{ha} \mathrm{hr}^{-1} \mathrm{yr}^{-1}$ ) [42]. In semi-arid Kenya, [43] also reported increases of $6.6,9.6$, and $10.6 \mathrm{t} \mathrm{C} \mathrm{ha}^{-1}$ in the $0-0.15 \mathrm{~m}$ depth after 15,18 and 23 years of exclosure establishment, respectively.

The sizeable differences in ECS between exclosures and free grazing lands can be explained in two ways. On the one hand, increased grazing pressure in the free grazing lands after the establishment of exclosures and susceptibility to erosion due to sparse vegetation cover would cause a further decrease in ECS in grazing lands. On the other hand, increased vegetation cover in exclosures would reduce erosion and increase organic matter input into the soil. [41] reported an increase of leaf, woody and reproductive organs litter input from $20 \mathrm{~g} \mathrm{~m}^{-2}$ in degraded grazing lands to nearly $600 \mathrm{~g} \mathrm{~m}^{-2}$ in 20-year-old exclosures. Comparing our estimated ECS increase (e.g., $1.4 \mathrm{t} \mathrm{C} \mathrm{ha}^{-1} \mathrm{yr}^{-1}$ under 20 year exclosure) after exclosure establishment with the soil carbon loss due to water erosion from grazing lands $\left(0.075 \mathrm{t} \mathrm{C}^{-1}\right.$ $\mathrm{yr}^{-1}$; [40] and fuelwood consumption $\left(0.31 \mathrm{t} \mathrm{C} \mathrm{ha}^{-1} \mathrm{yr}^{-1}\right.$; [44] so, the considerable differences in ECS between exclosures and grazing lands were largely due to carbon gained under exclosure.

Ecosystem carbon sequestration was also influenced by exclosure age. The relatively large increase in soil carbon storage compared to aboveground carbon in the first 10 years (Table 2) may have resulted from the sizable carbon input derived from herb and shrub biomass, from reduced soil erosion through improved ground cover, and from relatively slow decomposition under drier and cooler climate. Prohibition of grass harvesting during the first five to ten years improved under-canopy cover, which could reduce the erosive impact of raindrops and consequently soil erosion. The relatively drier and cooler climate could also restrict decomposition of organic matter, which consequently may favor the accumulation of soil carbon. The relatively slow increase of ecosystem carbon storage from 10 years to 15 years of exclosure establishment was possibly a manifestation of vegetation succession and of the partial removal of organic matter input through harvesting of grass or herbaceous biomass. Other studies conducted in the highlands and lowlands of Ethiopia have also shown that herbaceous/grass biomass and diversity decrease while shrub and tree abundance increase with exclosure age [4; 37].

The substantial increase in soil carbon under 20-year exclosures could be due to increase in carbon input under increasingly shrub- and tree-vegetated areas, and thus an increasing effect on preventing soil erosion. The 20 year exclosures were equivalent to the soil organic carbon level of the church forests studied by Wolde M. [11] in other parts of Tigray region, suggesting that at least two decades is required to increase the soil organic carbon in the free grazing lands to the level of the soil organic carbon in church forests through exclosure establishment. This pattern, however, does not mean that there is no more potential to sequester carbon after about 20 years. Church forests could possibly sequester a much larger carbon but the management practice allowed human and livestock activities to some degree.

The positive correlations of soil carbon with exclosure age support the influence of carbon input from vegetation to the soil. Other studies have also reported increasing soil carbon along with increasing plant species and aboveground biomass 
[45]. The increase in biomass cover with exclosure age (Table 1) could also reduce runoff and sediment-associated losses of soil organic carbon [40]. Exclosures of age 20 can accommodate $223.88 \mathrm{t} \mathrm{ha}^{-1} \mathrm{CO}_{2}$ equivalents compared with free grazing which accommodates $120.97 \mathrm{t} \mathrm{ha}^{-1} \mathrm{CO}_{2}$ equivalents which have a difference of $102.91 \mathrm{t} \mathrm{ha}^{-1} \mathrm{CO}_{2}$ equivalent and this means $5.15 \mathrm{t} \mathrm{ha}^{-1} \mathrm{yr}^{-1} \mathrm{CO}_{2}$ equivalents. This significant amount of biomass accommodation and carbon dioxide sequestration might be due to the following facts:

1. In the area exclosure, young plants might grow up without growth being hampered, but in the free grazing areas new emerging seedlings might be always grazed by or trampled by cattle, and the people might also be harvesting for want of cattle feed.

2. In the exclosures, the modification of the micro environment by the shade from emerging canopies could provide a suitable habitat to certain microorganisms and earthworms which might contribute to increase in soil fertility eventually facilitating biomass buildup.

3. Organic matter accumulation in the exclosure area contributes to water conservation and this might boost biomass increments.

Having the exclosure significant trees and shrubs biomass potential over the free grazing also shows that there might be significant fuelwood and construction material potential which is among the factors for the local people to treat exclosures sustainably [3]. In addition, such large amount of carbon dioxide sequestration difference also shows the contribution of closed areas to the global climate change mitigation, in addition to the modification of the the microclimate.

In the case of herbaceous biomass, though no increment in exclosures showed higher biomass in free grazing areas. Betru also found free grazing had more herbs than area closure [3]. Dereje et al., [46] identified protection for more than three years did not improve the diversity of herbaceous species and [4] attributed increased age of exclosures to shade from large trees hereby suppressing herbaceous growth. Therefore the herbs under the exclosures might be shaded and suppressed by the upper layer species.

Canopy cover refers to the proportion of the ground area covered by the vertical projection of the canopy [4]. Woody species cover is higher in exclosure than free grazed [4] [7]. Even though not significant, the present study also showed woody biomass coverage by tree and shrubs was higher in the exclosures than the free grazing area. This could be due to (i) differences from human and animal intervention (ii) modification of the environment by pre successor organisms (iii) bigger tree and shrubs contribution. This, in turn, might bring erosion control and further microclimate modification and organism attraction difference between the two sites since canopy intercept direct raindrop and the direct sun blazing. But, one reason for the exclosure not having higher herbaceous biomass coverage over the free grazing might be due to shedding effect of big trees and shrubs over the herbs [4].

\subsection{Referencing for Baseline Studies and Carbon Sequestration in Exclosure Projects}

To implement carbon sequestration projects using exclosures, it is necessary to have reliable baseline information which is typically lacking in countries like Ethiopia. In the present study, degraded free grazing lands as the baseline for exclosure projects and able to show that it is possible to make reliable estimates of carbon stocks in degraded free grazing lands using relatively simple methods. This is the first time that this is shown for a semiarid tropical region. Earlier baseline studies that used comparable methods were restricted to the humid tropics [47].

It is possible to make quantitative predictions of ecosystem carbon increments should exclosures be implemented on degraded free grazing lands. Such predictions are critical to analyzing whether exclosures are also an economically feasible alternative. In the case of Northern Ethiopia, Therefore, one could make the following prediction: taking an average increment of $28.04 \mathrm{tC} \mathrm{ha}^{-1}\left(61.0-32.96 \mathrm{t} \mathrm{C} \mathrm{ha}^{-1}\right)$ in exclosures compared to the adjacent grazing lands, the establishment of exclosures could increase ECS by $1.4 \mathrm{t} \mathrm{C}$ $\mathrm{ha}^{-1} \mathrm{yr}^{-1}$ in 20 years time. Using this annual increase in ECS, conversion of only $10 \%$ (107,054 ha) of the 1.1 million ha of degraded free grazing lands in the region [17] could sequester approximately $149,876 \mathrm{tC} \mathrm{yr}^{-1}$. If this is converted into carbon market, the income will significantly change the lives of the community. International carbon markets deal in carbon offsets, each offset being equal to one ton of $\mathrm{CO}_{2}$ sequestered by a forestry project. Carbon offsets are sold to international buyers at a higher price. After deducting from its overheads and commissions payable to brokers the project pays farmers at the rate of 4.5 USD per $\mathrm{tCO}_{2}$ in 2008 in USA [48]. For East Africa after estimated and actual transaction costs 3.64 USD per $\mathrm{tCO}_{2}$ was recommended by Timothy et al., [49] Based on this calculation the price of 149,876 $\mathrm{tC} \mathrm{yr}^{-1}$ is $550,045 \mathrm{tCO}_{2}$ equivalent and this will be 2,002,164.00 USD or $54,058,415.00$ ETB (with the current exchange rate 1 $\mathrm{USD}^{\approx} 27 \mathrm{ETB}$ ) per annum.

Establishment of exclosures on degraded free grazing lands has the potential to be considered in programs like Reducing Emissions from Degradation and Deforestation (REDD) which aim to generate financial compensation for increasing ECS and enhance sustainable development in developing countries. A crucial condition is, however, that this service is actually rewarded in order to provide sufficient incentives for the establishment of exclosures in the future.

The total carbon stock (carbon density) of the present study was $42.34 \pm 9.38 \mathrm{t} \mathrm{ha}^{-1}$ of which the carbon stock in the soil carbon pool was recorded as the largest $(37.75 \pm 7.15 \mathrm{t}$ $\left.\mathrm{ha}^{-1}\right)$. The majority of carbon in the terrestrial carbon pool is stored in soils, and the majority of it stored in forest biomes [50]. The carbon stock is relatively less compared to forests and parks studied before in Ethiopia but the encouraging change was observed in exclosures compared with free grazing areas. This may be due to the difference in vegetation type most of the studies are in forests, allometric equations 
used for biomass estimation, anthropogenic disturbance and other complex ecological factors. As stated by Yitebitu et al., [51], the different types of models used for biomass estimation have an impact on the value of carbon estimated in a given forest. The tree parameters used to calculate the biomass of the vegetation in the current study were only
DSH; others mostly used DBH basic wood density and height. On the other hand, previous studies did not only use DSH to estimate the biomass of the corresponding forests. Therefore, this may be one of the reasons that bring variation between carbon stocks of the vegetation in different parts of Ethiopia as well.

Table 6. Comparisons of the present study with previous studies.

\begin{tabular}{|c|c|c|c|c|c|c|c|}
\hline Study Area & AGC & BGC & $\mathbf{L C}$ & NTVC & SOC & Total & Reference \\
\hline 1. GARF & 217.27 & 43.54 & 5.08 & 2.20 & 172.62 & 440.71 & {$[62]$} \\
\hline 2. $\mathrm{MZ}$ & 237.39 & 47.56 & 6.49 & - & 57.67 & 348.86 & [63] \\
\hline 3. AMGWF & 414.70 & 83.48 & 1.28 & - & 83.80 & 583.18 & [64] \\
\hline 4. $\mathrm{EF}$ & 278.08 & 55.62 & 3.47 & - & 277.56 & 614.73 & [65] \\
\hline 5. MSSF & 133.00 & 26.99 & 5.26 & - & 121.28 & 286.53 & [66] \\
\hline 6. SCF & 122.85 & 25.97 & 4.95 & - & 135.94 & 289.71 & [67] \\
\hline 7. $\mathrm{CF}$ & 90.25 & 17.32 & 0.39 & 0.65 & 109.40 & 218.01 & [68] \\
\hline 8. TGF & 306.37 & 61.52 & 0.90 & & 274.32 & 643.11 & [69] \\
\hline 9. ВССРР & 25.4 & 5.1 & 5.17 & & 113.55 & 149.22 & [70] \\
\hline 10. MGF & 146.34 & 29.27 & 3.03 & & 131.79 & 310.43 & [71] \\
\hline 11. DCF & 277.78 & 41.65 & 1.06 & 0.4 & 186.4 & 507.29 & [61] \\
\hline 12. $\mathrm{BF}$ & 338.72 & 67.74 & 2.58 & & 230.82 & 639.86 & [72] \\
\hline 13. HF (Tanzania) & 48.37 & - & - & 0.26 & 45.71 & 94.34 & {$[28]$} \\
\hline 14. FGT & 0.81 & 0.16 & - & 1.39 & 30.60 & 32.96 & Current Study \\
\hline 15. EXT & 4.73 & 0.95 & - & 1.14 & 44.90 & 51.72 & Current Study \\
\hline
\end{tabular}

Note: $\mathrm{AGC}=$ aboveground carbon, $\mathrm{BGC}=$ belowground carbon, $\mathrm{LC}=$ litter carbon, NTVC $=$ non-tree vegetation carbon and SOC $=$ soil organic carbon. GARF- Gera Afromontane Rainforest, MZ- Mount Zequalla, AMGWF- Arba Minch Ground Water forest, EF- Egdu Forest, MSSF- Menagesha Suba State Forest, SCF- Selected Church Forest, CF- Chilmo Forest, TGF- Tara Gedam Forest, BCCPP- Biheretsige and Central Closed Public Park, MGF-Meskele Gedam Forest, DCF- Danaba Community Forest, BF- Banja Forest and HF- Hanang Forest. FGT- Free grazing in Tigray and EXT- Exclosures in Tigray.

Despite the fact that the present study was conducted in a non-forest vegetation type, the vegetation in exclosures was contributing comparable ecosystem carbon storage. According to the assessment of Achard et al., [52], on Biome-average tropical forest biomass carbon stock estimates and implications for the global carbon cycle, the average carbon stock of Sub-Saharan Africa, Tropical Asia, and Brazilian Amazon forests are 143, 151, $186 \mathrm{t} \cdot \mathrm{ha}^{-1}$, respectively. Therefore, comparatively very low values were obtained relative to previous continental assessments. On the other hand, the mean biomass carbon stocks of trees in the natural forest of Hanang Forest is $94.34 \mathrm{t} \cdot \mathrm{ha}^{-1}$ [28], and Community Forest (CF) of Mid Hill Region of Nepal is $71.36 \mathrm{t} \cdot \mathrm{ha}^{-1}$ [53]. Hence, the present study was almost similar to those carbon densities of Hanang Forest in Tanzania and CF of Mid Hill Region of Nepal (Table 6).

However, the result of mean above- and below-ground tree carbon stock was less than almost all of the previous Ethiopian studies of woody biomass carbon. The variation may be due to the difference in vegetation type, variation of the age of the trees, the type of species, regional variability in soil, topography, and management regime of the forests [54]. The allometric model used in biomass estimation might also have a slight role for the difference in estimated values [55]. Similarly, the overall herbaceous biomass contribution to carbon density was very minimal. On the other hand, relatively higher values were obtained in the present study than in Danaba Community Forest and Chilmo Forest.

The reason for tropical forests may be due to huge closed canopies of Juniperus procera and Podocarpus falcatus up to the near ground making the growth of herbs and grasses unsuitable. This is not the case in the study area. The carbon stock estimated from the herbaceous carbon pool was higher than in the free grazing area. This may be due to low tree density per hectare which creates a more suitable habitat for undergrowth vegetation. SOC globally increases with precipitation and clay content, even though it is mainly determined by carbon output (decomposition), and decreases with increase in temperature and as exclosure age increase decomposition is increasing [31]. SOC values were less than those for other forest areas, and only comparable to that of Mount Zequalla in Ethiopia and Hanang Forest in Tanzania (Table 6). As the study area was highly degraded and found on high elevation and slopy ground there is high probability for loss of litter through runoff before decomposition without much contribution to SOM. Rainfall and temperature variation of the studies might also have a contribution to this variation. In other forest areas, according to Sheikh et al., [56] the higher mean SOC stock may be due to the presence of high SOM and fast decomposition of litter which results in maximum storage of carbon stock.

Forests have a large potential for temporary and long-term carbon storage [57] and the forest biomass and carbon stock is influenced by altitudinal variations [58]. Murphy and Lugo [59], pointed out that the global pattern in aboveground biomass in tropical dry and wet forests ranged between 30 275 and 213-1173 t. ha ${ }^{-1}$, respectively, and reported 13.5$122.85 \mathrm{t}^{-\mathrm{ha}^{-1}}$ and $95-527.85 \mathrm{t}$. ha ${ }^{-1}$, for the global aboveground carbon stock in tropical dry and wet forests respectively. The result of the present study showed that aboveground biomass in 20 years exclosure is almost similar to aboveground biomass in tropical dry forests. 
A large amount of carbon stock has been observed in a species which has counted long lived in the study site and also species which are densely populated in the pool. As a result, this study indicates the unbalanced tendency of carbon stock input in the above-ground of the site. In the exclosures, high biomass rate has been recorded by species such as Astragalus atropilosulus, Euphorbia abyssinica, Acacia asak and Cordia africana whereas species such as Myrsine africana, Rhus glutinosa, andRhamnus prinoides had less biomass. In free grazing areas, high biomass has been recorded by species such as Euphorbia abyssinica, Acacia etbaica, Stereospermum kunthianum and Ricinus communis whereas species such as Acokanthera schimperi, Schinus molle, andEuclea racemosa had less biomass.

In the study area, SOC negatively correlated with altitude and had shown a relatively decreasing trend with increasing altitude though there was no significant variation in carbon along the same. Although slope was positively correlated with SOC, the result were not significant. Similarly, the effects of slope on Banja Forest carbon stocks were very small and the relations were insignificant for all carbon pools which is similar to other studies of Apennine Beech Forest in Italy [60] and Danaba Community Forest in Ethiopia [61] with a slightly small variation among slope classes.

From this study it could be generalised that exclosures contained a large amount of $\mathrm{CO}_{2}$ contributing to the mitigation effort in combating impacts of global climate change.

\section{Conclusion}

The results of the present study confirm that establishment of exclosures on degraded free grazing lands in the Northern Highlands of Ethiopian is a viable option to restore ECS. The study showed that ECS in exclosures, in free grazing lands and the change in ECS following the establishment of exclosures on free grazing lands can be predicted using easily measurable biophysical and management-related indicators. Such information is necessary for the establishment of baseline information for carbon sequestration projects, for evaluation of whether exclosure establishment should be expanded, and for policymakers to take into account the value of exclosures in their management decisions. Although the study showed that exclosures are effective to restore ECS, expansion of exclosures would increase grazing pressure on the remaining free grazing area. Therefore, the decision to establish additional exclosures should also include an economical analysis and an evaluation of the social consequences of such a decision.

\section{Recommendations}

Considering exclosures as Green Development Mechanisms (GDM) projects and thereby generating financial compensation to support the local communities in their efforts to restore free degraded lands might be a way to increase economic benefits for local communities. However, as carbon market revenues will hardly be sufficient to make exclosures competitive to other land uses, additional (e.g. public) funds could be means to reward soil restoration services, thereby ensuring future nutrient availability.

Before expanding the area covered by exclosures, it is crucial to consider forest management options such as enrichment plantation of indigenous woody species that can grow fast in exclosures to address the shortage of fuelwood and improve future ecological and economical benefits of the exclosures.

As fuelwood shortages are one of the concerns for the negative impacts of exclosures raised by the local communities, enhancing fuelwood supply from exclosures could reduce resistance from the local communities while planning to expand the area covered by exclosures. Moreover, transferring the direct and indirect benefits of exclosures into payments for the respective ecosystem services could increase the interest of the local communities on exclosures.

Special attention should be given to solve the shortage of grazing land due to exclosure so as to encourage community's interest in expanding and managing exclosure practices in their locality.

\section{Acknowledgements}

The corresponding author acknowledges International Foundation for Sciences (IFS) of Sweden under their IFS Grant No: D/5765-1, Department of Plant Biology and Biodiversity Management of AAU, and Mekelle University for their financial and logistical supports.

\section{Appendix}

Table 7. List of Species, family, life form and local names in the study area.

\begin{tabular}{lll}
\hline No. & Species & Family \\
\hline 1 & Abutilon longicuspe Hochst. ex A. Rich. & Malvaceae \\
2 & Acacia abyssinica Hochst. ex Benth. & Fabaceae \\
3 & Acacia asak (Forssk.) Willd. & Fabaceae \\
4 & Acacia decurrens Willd. & Fabaceae \\
5 & Acacia etbaica Schweinf. & Fabaceae \\
6 & Acacia mellifera (Vahl.) Benth. & Fabaceae \\
7 & Acacia saligna (Labill.) Wendl. & Fabaceae \\
8 & Acacia seyal Del. & Fabaceae \\
9 & Acacia tortilis (Forsk) Hayne. & Fabaceae \\
\hline
\end{tabular}




\begin{tabular}{|c|c|c|c|}
\hline No. & Species & Family & life form \\
\hline 10 & Acanthospermum hispidum DC. & Asteraceae & $\mathrm{H}$ \\
\hline 11 & Achyranthes aspera $\mathrm{L}$. & Amaranthaceae & $\mathrm{H}$ \\
\hline 12 & Acokanthera schimperi (A. DC.) Schweinf. & Apocynaceae & $\mathrm{S} / \mathrm{T}$ \\
\hline 13 & Ageratum conyzoides L. & Asteraceae & $\mathrm{H}$ \\
\hline 14 & Amaranthus hybridus L. & Acanthaceae & $\mathrm{H}$ \\
\hline 15 & Andropogon distachyos $\mathrm{L}$. & Poaceae & $\mathrm{H}$ \\
\hline 16 & Argemone mexicana $\mathrm{L}$. & Papaveraceae & $\mathrm{H}$ \\
\hline 17 & Asparagus racemosus Willd. & Asparagaceae & $\mathrm{H} / \mathrm{CH}$ \\
\hline 18 & Astragalus atropilosulus (Hochst.) Bunge. & Fabaceae & $\mathrm{S}$ \\
\hline 19 & Asystasia schimperi $\mathrm{T}$. Anders. & Acanthaceae & $\mathrm{H}$ \\
\hline 20 & Barleria orbicularis Hochst. ex T. Anders. & Acanthaceae & $\mathrm{S}$ \\
\hline 21 & Barleria ventricosa Hochest. ex Nees. & Acanthaceae & $\mathrm{H}$ \\
\hline 22 & Becium grandiflorum (Lam.) Pic. Serm. & Lamiaceae & $\mathrm{S}$ \\
\hline 23 & Berberis holstii Engl. & Berberidaceae & $\mathrm{S} / \mathrm{T}$ \\
\hline 24 & Bersama abyssinica Fresen. & Melianthaceae & $\mathrm{T}$ \\
\hline 25 & Bidens macroptera (Sch. Bip. ex Chiov.) Mesfin. & Acanthaceae & $\mathrm{H}$ \\
\hline 26 & Bidens pilosa $\mathrm{L}$. & Acanthaceae & $\mathrm{H}$ \\
\hline 27 & Boscia angustifolia A. Rich. & Capparaceae & $\mathrm{T}$ \\
\hline 28 & Brachiaria Spp. & Poaceae & $\mathrm{H}$ \\
\hline 29 & Cadia purpurea (Picc.) Ait. & Fabaceae & $\mathrm{S}$ \\
\hline 30 & Calpurinia aurea (Ait.)Benth. & Fabaceae & $\mathrm{S} / \mathrm{T}$ \\
\hline 31 & Canthium setiflorum sensu Cufod. nonHiern. & Rubiaceae & $\mathrm{S}$ \\
\hline 32 & Capparis tomentosa Lam. & Capparaceae & $\mathrm{S} / \mathrm{T}$ \\
\hline 33 & Carica papaya $\mathrm{L}$. & Caricaceae & $\mathrm{T}$ \\
\hline 34 & Carissa edulis Wahl. & Apocynaceae & $\mathrm{S}$ \\
\hline 35 & Cassipourea malosana (Baker) Alston & Rhizophoraceae & $\mathrm{T}$ \\
\hline 36 & Celtis africana Burm. $\mathrm{f}$ & Ulmaceae & $\mathrm{T}$ \\
\hline 37 & Cenchrus ciliaris $\mathrm{L}$. & Poaceae & $\mathrm{H}$ \\
\hline 38 & Chamaecrista hochstetteri (Ghesq.) Lock. & Fabaceae & $\mathrm{S}$ \\
\hline 39 & Chenopodium murale $\mathrm{L}$. & Chenopodiaceae & $\mathrm{H}$ \\
\hline 40 & Chloris pycnothrix Trin. & Poaceae & $\mathrm{H}$ \\
\hline 41 & Clutia abyssinica Jaub. \& Spach. & Euphorbiaceae & $\mathrm{S}$ \\
\hline 42 & Colutea abyssinica Kunth. \& Bouche. & Fabaceae & $\mathrm{S}$ \\
\hline 43 & Commiphora africana (A. Rich.) Engl. & Burseraceae & $\mathrm{T}$ \\
\hline 44 & Cordia africana Lam. & Boraginaceae & $\mathrm{T}$ \\
\hline 45 & Cupressus lusitanica Mill. & Cupressaceae & $\mathrm{T}$ \\
\hline 46 & Cymbopogon caesius (Hook.\& Arn.) Stapf. & Poaceae & $\mathrm{H}$ \\
\hline 47 & Cynodon dactylon (L.) Pers. & Poaceae & $\mathrm{H}$ \\
\hline 48 & Cyperus bulbosus Vahl. & Cyperaceae & $\mathrm{H}$ \\
\hline 49 & Cyperus longus $\mathrm{L}$. & Cyperaceae & $\mathrm{H}$ \\
\hline 50 & Datura stramonium $\mathrm{L}$. & Solanaceae & $\mathrm{H}$ \\
\hline 51 & Delonix regia (Boj. ex Hook.) Raf. & Fabaceae & $\mathrm{T}$ \\
\hline 52 & Dichrostachys cinerea (L.) Wight \& Arn. & Fabaceae & $\mathrm{S} / \mathrm{T}$ \\
\hline 53 & Digitaria abyssinica (Hochst. ex A. Rich.) Stapf. & Poaceae & $\mathrm{H}$ \\
\hline 54 & Digitaria ternate (A. Rich.) Stapf. & Poaceae & $\mathrm{H}$ \\
\hline 55 & Dodonea angustifolia L. f. & Sapindaceae & $\mathrm{S}$ \\
\hline 56 & Dombeya torrida (J. F. Gmel.) P. Bamps. & Sterculiaceae & $\mathrm{S} / \mathrm{T}$ \\
\hline 57 & Dovyalis abyssinica (A. Rich.) Warb. & Flacourtiaceae & $\mathrm{S} / \mathrm{T}$ \\
\hline 58 & Dovyalis verrucosa (Hochst.) Warb. & Flacourtiaceae & $\mathrm{S} / \mathrm{T}$ \\
\hline 59 & Ehretia cymosa Thonn. & Boraginaceae & $\mathrm{S} / \mathrm{T}$ \\
\hline 60 & Eleusine floccifolia (Forsk.) Spreng. & Poaceae & $\mathrm{H}$ \\
\hline 61 & Eleusine indica (L.) Gaertn. & Poaceae & $\mathrm{H}$ \\
\hline 62 & Eragrostis papposa (Roem. \& Schult.) Steud. & Poaceae & $\mathrm{H}$ \\
\hline 63 & Eragrostis tenuifolia (A. Rich.) Steud. & Poaceae & $\mathrm{H}$ \\
\hline 64 & Erucastrum arabicum Fisch. \& Mey. & Crucifereae & $\mathrm{H}$ \\
\hline 65 & Eucalyptus camaldulensis Dehnh. & Myrtaceae & $\mathrm{T}$ \\
\hline 66 & Eucalyptus globules Labill. & Myrtaceae & $\mathrm{T}$ \\
\hline 67 & Euclea racemosa Murr. subsp. schimperi (A. DC.) White. & Ebenaceae & $\mathrm{S}$ \\
\hline 68 & Euclea schimperi (A. DC.) Dandy. & Ebenaceae & $\mathrm{S}$ \\
\hline 69 & Euphorbia abyssinica Gmel. & Euphorbiaceae & $\mathrm{T}$ \\
\hline 70 & Exotheca abyssinica (Hochst. ex A. Rich.) Anderss. & Poaceae & $\mathrm{H}$ \\
\hline 71 & Faidherbia albida (Del.) A. Chev. & Fabaceae & $\mathrm{T}$ \\
\hline 72 & Ficus palmata Forssk. & Moraceae & $\mathrm{S} / \mathrm{T}$ \\
\hline 73 & Flaveria trinervia (Spreng.) C. Mohr. & Asteraceae & $\mathrm{H}$ \\
\hline 74 & Galium spurium $\mathrm{L}$. & Rubiaceae & $\mathrm{H}$ \\
\hline 75 & Grewia ferruginea Hochst. ex A. Rich. & Tiliaceae & $\mathrm{S} / \mathrm{T}$ \\
\hline 76 & Grewia $s p$. & Tiliaceae & $\mathrm{S} / \mathrm{T}$ \\
\hline
\end{tabular}




\begin{tabular}{|c|c|c|c|}
\hline No. & Species & Family & life form \\
\hline 77 & Heteromorpha trifoliata (Wendel.) Eckl. and Zeyh. & Apiaceae & $\mathrm{S}$ \\
\hline 78 & Hibiscus ovalifolius (Forssk.) Vahl. & Malvaceae & $\mathrm{H}$ \\
\hline 79 & Hyparrhenia hirta (L.) Stapf. & Poaceae & $\mathrm{H}$ \\
\hline 80 & Hyparrhenia rufa (Nees.) Stapf. & Poaceae & $\mathrm{H}$ \\
\hline 81 & Hypoestes forskaolii (Vahl) R. Br. & Acanthaceae & $\mathrm{H}$ \\
\hline 82 & Imperata cylindrica (L.) Raeusch. & Poaceae & $\mathrm{H}$ \\
\hline 83 & Indigofera arrecta Hochst. ex A. Rich. & Fabaceae & $\mathrm{S}$ \\
\hline 84 & Ipomoea sinensis (Desr.) Choisy. & Convolvulaceae & $\mathrm{H}$ \\
\hline 85 & Juniperus procera Hochst. ex Endl. & Cupressaceae & $\mathrm{T}$ \\
\hline 86 & Kalanchoe sp. & Crassulaceae & $\mathrm{S}$ \\
\hline 87 & Lactuca inermis Forssk & Asteraceae & $\mathrm{H}$ \\
\hline 88 & Laggera tomentosa (Sch. Bip. ex A. Rich.) Oliv. \& Hiern & Asteraceae & $\mathrm{S}$ \\
\hline 89 & Leucaena leucocephala (Lam.) De Wit. & Fabaceae & $\mathrm{T}$ \\
\hline 90 & Leucas abyssinica (Benth.) Briq. & Lamiaceae & $\mathrm{H}$ \\
\hline 91 & Malva verticillata $\mathrm{L}$. & Malvaceae & $\mathrm{H}$ \\
\hline 92 & Maytenus senegalensis (Lam.) Exell & Celastraceae & $\mathrm{S} / \mathrm{T}$ \\
\hline 93 & Mentha longifolia (L.) Hudson & Lamiaceae & $\mathrm{H}$ \\
\hline 94 & Myrsine africana $\mathrm{L}$. & Myrsinaceae & $\mathrm{S}$ \\
\hline 95 & Ocimum urticifolium Roth & Lamiaceae & $\mathrm{H}$ \\
\hline 96 & Olea europaea L. subsp. cuspidata (Wall. ex G. Don) Cif. & Oleaceae & $\mathrm{T}$ \\
\hline 97 & Olinia rochetiana A. Juss. & Oliniaceae & $\mathrm{S} / \mathrm{T}$ \\
\hline 98 & Opuntia ficus-indica (L.) Miller. & Cactaceae & $\mathrm{S}$ \\
\hline 99 & Osteospermum vailliantii (Decne.) T. Norl. & Asteraceae & $\mathrm{H}$ \\
\hline 100 & Osyris quadripartita Decn. & Santalaceae & $\mathrm{S} / \mathrm{T}$ \\
\hline 101 & Oxygonum sinuatum (Meisn.) Dammer. & Polygonaceae & $\mathrm{H}$ \\
\hline 102 & Panicum maximum Jacq. & Poaceae & $\mathrm{H}$ \\
\hline 103 & Parthenium hysterophorus $\mathrm{L}$. & Acanthaceae & $\mathrm{H}$ \\
\hline 104 & Pennisetum sphacelatum (Nees) Th. Dur. \&Schinz & Poaceae & $\mathrm{H}$ \\
\hline 105 & Pennisetum unisetum (Nees.) Benth. & Poaceae & $\mathrm{H}$ \\
\hline 106 & Phagnalon abyssinicum Sch. Bip. ex A. Rich. & Asteraceae & $\mathrm{H}$ \\
\hline 107 & Phytolacca dodecandra L'Hérit. & Phytolaccaceae & $\mathrm{S}$ \\
\hline 108 & Pittosporum viridiflorum Sims. & Pittosporaceae & $\mathrm{T}$ \\
\hline 109 & Plumbago zeylanica $\mathrm{L}$. & Pulumbaginaceae & $\mathrm{H}$ \\
\hline 110 & Poa leptoclada Hochst. ex A. Rich. & Poaceae & $\mathrm{H}$ \\
\hline 111 & Psydrax schimperiana (A. Rich.) Bridson. & Rubiaceae & $\mathrm{S} / \mathrm{T}$ \\
\hline 112 & Pterolobium stellatum (Forssk.) Brenan. & Fabaceae & $\mathrm{CS}$ \\
\hline 113 & Rhamnus prinoides L'Hérit. & Rhamnaceae & S \\
\hline 114 & Rhus glutinosa A. Rich. & Anacardiaceae & $\mathrm{T}$ \\
\hline 115 & Rhus natalensis Krauss. & Anacardiaceae & $\mathrm{T}$ \\
\hline 116 & Rhus vulgaris Meikle. & Anacardiaceae & $\mathrm{S} / \mathrm{T}$ \\
\hline 117 & Ricinus communis $\mathrm{L}$. & Euphorbiaceae & $\mathrm{S} / \mathrm{T}$ \\
\hline 118 & Rosa abyssinica Lindley. & Rosaceae & $\mathrm{S}$ \\
\hline 119 & Rumex abyssinicus Jacq. & Polygonaceae & $\mathrm{H}$ \\
\hline 120 & Rumex nepalensis Spreng. & Polygonaceae & $\mathrm{H}$ \\
\hline 121 & Rumex nervosus Vahl. & Polygonaceae & $\mathrm{H} / \mathrm{S}$ \\
\hline 122 & Sageretia thea (Osbeck) M. C. Johnston. & Rhamnaceae & S \\
\hline 123 & Schinus molle L. & Anacardiaceae & $\mathrm{T}$ \\
\hline 124 & Senna singueana (Del.) Lock & Fabaceae & $\mathrm{S}$ \\
\hline 125 & Sesbania sesban (L.) Merr. & Fabaceae & $\mathrm{S}$ \\
\hline 126 & Setaria verticilliata (L.) P. Beauv. & Poaceae & $\mathrm{H}$ \\
\hline 127 & Silene burchellii DC. & Caryophyllaceae & $\mathrm{H}$ \\
\hline 128 & Solanum incanum $\mathrm{L}$. & Solanaceae & $\mathrm{H} / \mathrm{S}$ \\
\hline 129 & Solanum nigrum $\mathrm{L}$. & Solanaceae & $\mathrm{H}$ \\
\hline 130 & Solanum schimperianum Hochst. ex A. Rich. & Solanaceae & $\mathrm{H} / \mathrm{S}$ \\
\hline 131 & Sonchus oleraceus $\mathrm{L}$. & Asteraceae & $\mathrm{H}$ \\
\hline 132 & Sporobolus pyramidalis P. Beauv. & Poaceae & $\mathrm{H}$ \\
\hline 133 & Stereospermum kunthianum Cham. & Bignoniaceae & $\mathrm{T}$ \\
\hline 134 & Tagetes minuta $\mathrm{L}$. & Asteraceae & $\mathrm{H}$ \\
\hline 135 & Teclea simplicifolia (Engl.) Verdoorn & Rutaceae & $\mathrm{T}$ \\
\hline 136 & Tephrosia interrupta Hochst. \& Steud. ex Engl. & Fabaceae & $\mathrm{S}$ \\
\hline 137 & Tribulus terrestris $\mathrm{L}$. & Zygophyllaceae & $\mathrm{H}$ \\
\hline 138 & Trifolium baccarinii Chiov. & Fabaceae & $\mathrm{H}$ \\
\hline 139 & Vernonia amygdalina Del. & Asteraceae & $\mathrm{S} / \mathrm{T}$ \\
\hline 140 & Xanthium spinosum L. & Asteraceae & $\mathrm{H}$ \\
\hline 141 & Xanthium strumarium L. & Asteraceae & $\mathrm{H}$ \\
\hline 142 & Ziziphus spina-christi (L.) Desf. & Rhamnaceae & $\mathrm{S} / \mathrm{T}$ \\
\hline
\end{tabular}


Table 8. Biomass Formula for species based on WBISPP 2000.

\begin{tabular}{|c|c|c|c|}
\hline Species & Family & life form & Biomass formula \\
\hline Rhus vulgaris & Anacardiaceae & Shrub/Tree & $(0.0038 * \mathrm{DSH})+(0.6092 *(\mathrm{DSH} \exp 1.5))$ \\
\hline Pittosporum viridiflorum & Pittosporaceae & Tree & $(0.0051 * \mathrm{DSH})+(0.6359 *(\mathrm{DSH} \exp 1.2))$ \\
\hline Ehretia cymosa & Boraginaceae & Shrub/Tree & $(0.0197 * \mathrm{DSH})+(0.2344 *(\mathrm{DSH} \exp 1.8))$ \\
\hline Rhus natalensis & Anacardiaceae & Tree & $(0.0281 * \mathrm{DSH})+(0.1505 *(\mathrm{DSH} \exp 2.3))$ \\
\hline Vernonia amygdalina & Asteraceae & Shrub/Tree & $(0.0299 * \mathrm{DSH})+(0.0206 *(\mathrm{DSH} \exp 3.0))$ \\
\hline Ziziphus spina-christi & Rhamnaceae & Shrub/Tree & $(0.0340 * \mathrm{DSH})+(0.0431 *(\mathrm{DSH} \exp 2.6))$ \\
\hline Acacia mellifera & Fabaceae & Tree & $(0.0627 * \mathrm{DSH})+(0.3091 *(\mathrm{DSH} \exp 1.9))$ \\
\hline Acacia etbaica & Fabaceae & Tree & $(-0.1024 * \mathrm{DSH})+(0.1502 *(\mathrm{DSH} \exp 2.3))$ \\
\hline Acacia seyal & Fabaceae & Tree & $(0.1124 * \mathrm{DSH})+(0.1238 *(\mathrm{DSH} \exp 2.4))$ \\
\hline Bersama abyssinica & Melianthaceae & Tree & $(0.1189 * \mathrm{DSH})+(0.0011 *(\mathrm{DSH} \exp 4))$ \\
\hline Dodonea angustifolia & Sapindaceae & Shrub & $(0.1505 * \mathrm{DSH})+(0.0122 *(\mathrm{DSH} \exp 2.0))$ \\
\hline Acokanthera schimperi & Apocynaceae & Shrub/Tree & $(0.2383 * \mathrm{DSH})+(0.2211 *(\mathrm{DSH} \exp 1.9))$ \\
\hline Teclea simplicifolia & Rutaceae & Tree & $(0.2896 * \mathrm{DSH})+(2.6451 *(\mathrm{DSH} \exp 1.1))$ \\
\hline Stereospermum kunthianum & Bignoniaceae & Tree & $(0.3513 * \mathrm{DSH})+(0.0032 *(\mathrm{DSH} \exp 3.1))$ \\
\hline Grewia ferruginea & Tiliaceae & Shrub/Tree & $(0.5983 * \mathrm{DSH})+(0.0017 *(\mathrm{DSH} \exp 3.7))$ \\
\hline Dombeya torrida & Sterculiaceae & Shrub/Tree & $(0.8630 * \mathrm{DSH})+(0.0744 *(\mathrm{DSH} \exp 1.2))$ \\
\hline Acacia abyssinica & Fabaceae & Tree & $(1.0497 * \mathrm{DSH})+(0.0300 *(\mathrm{DSH} \exp 2.8))$ \\
\hline Acacia tortilis & Fabaceae & Tree & $(1.1725 * \mathrm{DSH})+(0.0106 *(\mathrm{DSH} \exp 3))$ \\
\hline All the rest species & & & $(1.4277 * \mathrm{DSH})+(0.0088 *(\mathrm{DSH} \exp 3.0))$ \\
\hline
\end{tabular}

\section{References}

[1] Stocking, M., and Murnaghan, N. (2001). Handbook for the field assessment of land degradation. Earthscan publications Ltd, London, Stering VA. 169p.

[2] UNFPA and POPIN (1995). Population and Land Degradation. FAO/ UNFPA TSS.

[3] Betru, N., Jawad, A., and Ingrid, N. (2005). Exploring ecological and socio-Economic issues for the improvement of area enclosure management: A Case Study from Ethiopia. DCG Report No. 38. May 22005. Pp 3-30.

[4] Yayneshet, T., Eik, L. O. and Moe, S. R. (2009). The effects of exclosures in restoring degraded semi-arid vegetation in communal grazing lands in northern Ethiopia. Journal of Arid Environments 73 (5): 542-549.

[5] Dasgupta, P. and Maler, K. G. (1994). Poverty, Institutions and the environmental resource base, World Bank Environment paper 9. World Bank. Washington D. C.

[6] Hurni, H., Kebede, T., Gete, Z. (2005). The implications of changes in population, land use, and land management for surface runoff in the Upper Nile Basin area of Ethiopia. Mt. Res. Dev. 25: 145-149.

[7] Emiru, B., Demel, T., and Barklund, P. (2007). Enclosures to enhance woody species diversity in the drylands of Tigray. East African Journal of Science, 1: 136-147.

[8] REST (Relief Society of Tigray). (1998). Soil andWater Conservation Programme. REST, Mekelle, Ethiopia.

[9] Tucker, N. I., and Murphy, T. M., (1997). The effects of ecological rehabilitations on vegetation recruitment: some observations from the wet Tropics of North Queensland. Forest Ecology and Management99: 133 - 144.

[10] WFP/MoA (2002). (World Food Program/Ministry of Agriculture. Impact assessment of the ETH-2488/MERET
Project (Interim Report). Ministry of Agriculture. Addis Ababa, Ethiopia.

[11] Wolde, M., Veldkamp, E., Mitiku, H., Kindeya, G., Muys, B., and Nyssen, J. (2009). Effectiveness of exclosures to control soil erosion and local community perception on soil erosion in Tigray, Ethiopia. African Journal of Agricultural Research 4: 365-377.

[12] Ravindranath, N. H., Somashekhar, B. S. and Gadgil, M. (1997). Carbon flow in Indian forests. Clim. Chang. 35: 297-320.

[13] FSI. (1988). The state of Forest Report 1987, Ministry of Environment and Forests. India.

[14] Soil Survey Staff. (1996). Keys to Soil Taxonomy. Seventh edition. United States Department of Agriculture, Washington DC.

[15] Gebrekidan, T., (2004). Impact of free grazing and open access to communal lands on Natural Resource: The case of Tigray Regional state in Ethiopia. Ethiopian Journal of Natural Resources 6 (1): 55-69.

[16] Asfawossen, A. (2002). The Rock-Hewn churches of Tigrai, northern Ethiopia: A geological perspective. Geoarchaeology 17: 649-663.

[17] BoANRD. (2010). Bureau of agriculture and natural resources of Tigray: Five-year implementation plan. Mekelle, Ethiopia. Unpublished.

[18] Pickett S. Space-for-time substitution as an alternative to longterm studies. In: Likens GE, editor. Long-Term Studies in Ecology: Approaches and Alternatives. New York: Springer; 1989. pp. 110-135.

[19] Smartt, P. F. (1978). Sampling for vegetation survey: a flexible systematic model for sample location. Journal of Biogeography 5 (1): 43-56.

[20] Kent, M. and Coker, P. (1992). Vegetation Description and Analysis: A practical approach. New York: John Wiley and Sons Ltd. 363pp. 
[21] Getinet, M. (2014). Diversity, Structure, Regeneration, and Status of Vegetation in Simien Mountains National Park, Northern Ethiopia. Ph. D. Dissertation, Addis Ababa University, Ethiopia.

[22] Van der Maarel, E. (1979). Transformation of cover/abundance values in phytosociology and its effect on community similarity. Vegetatio 39 : 97-114.

[23] Walkley, A., and Black. I. A. (1934). An examination of the Degtjareff method for determining organic carbon in soils: effect of variations in digestion conditions and of inorganic soil constituents. Soil Sci.63: 251-263.

[24] Blake, G. R., and Hartge, K. H. (1986). Bulk density. In: Klute, A. (ed.), Methods of soil analysis: part 1. Physical and mineralogical methods, ASA Monograph9: 363-375.

[25] Gee, G. W., and Bauder, J. W. (1982). Particle size analysis. In: Klute, A. (ed.), Methods of soil analysis: part 1. Physical and mineralogical methods, ASA Monograph9: 383-411.

[26] Baker, T. R., Philips, O. L., Malhi, Y, Almeida, S., Arroyo, L. and Di Fiore, A. (2004). Variation in wood density determines spatial patterns in Amazonian forest biomass. Global Change Biology10: 545-562.

[27] WBISPP (Woody Biomass Inventory and Strategic Planning Project). (2000). Manual for woody biomass inventory. Woody Biomass Inventory and Strategic Planning Project, Ministry of Agriculture, Addiss Ababa, Ethiopia.

[28] Swai, G., Ndangalasi, H., Munishi, P., and Shirima, D. (2014). Carbon Stocks of Hanang forest, Tanzania: An Implication for Climate Mitigation. Journal of Ecology and Natural Environment 6 (3): 90-98.

[29] Pearson, T., Brown, S., and Birdsey, R. (2007). Measurement Guidelines for the Sequestration of Forest carbon. Northern Research Station, Department of Agriculture, Washington, D. C.

[30] Gibbs, H., Brown, S., Niles, J., and Foley, J. (2007). Monitoring and Estimating Tropical Forest Carbon Stocks: Making REDD a Reality. Environment Research Letter 2 (4): 045023 doi:10.1088/1748-9326/2/4/045023.

[31] Zhu, B., Wang, X., Fang, J., Piao, S., Shen, H., Zhao, S. and Peng, C. (2010). Altitudinal Changes in Carbon Storage of Temperate Forests on Mt Changbai, Northeast China. Journal of Plant Research 123 (4): 39-52.

[32] Brown, S., Shoch D., Pearson, T., and Delaney, M. (2004). Methods for Measuring and Monitoring Forestry Carbon Projects in California. Winrock International, for the California Energy Commission, PIER Energy-Related Environmental Research. 500-04-072F.

[33] Verdoodt, A., Mureithi, S. M., and Ranst, E. V. (2010). Impacts of management and enclosure age on recovery of the herbaceous rangeland vegetation in semi-arid Kenya. Journal ofArid Environments 74: 1066-1073.

[34] Muchiru, A. N., Western, D., and Reid, R. S. (2009). The impact of abandoned pastoral settlements on plant and nutrient succession in an African savanna ecosystem. Journalof Arid Environments 73: 322-331.

[35] Hosseinzadeh, G., Jalilvand, H., and Tamartash, R. (2010). Short term impacts of enclosure on vegetation cover, productivity, and some physical and chemical soil properties. Journalof Applied Sciences 10: 2001-2009.
[36] Carpenter, F. L., Mayorga, S. P., Quintero, E. G., \& Schroeder, M. (2001). Land-use and erosion of a Costa Rican Ultisol affect soil chemistry, mycorrhizal fungi, and early regeneration. Forest Ecology and Management 144: 1-17.

[37] Ayana, A., and Oba, G. (2010). Effects of grazing pressure, age of enclosures and seasonality on bush cover dynamics and vegetation composition in southern Ethiopia. J. Arid Environ.74: 111-120.

[38] Smit, G. N., Richter, C. G., and Aucamp, A. J. (1999). Bush encroachment: an approach to understanding and managing the problem. In: Tainton, N. M. (ed.), Veld Management in South Africa. University of Natal Press, Pietermaritzburg, South Africa. pp. 246-260.

[39] Woldeamlak, B., and Stroonijder, L. (2003). Effects of agroecological land use succession on soil properties in Chemoga watershed, Blue Nile basin, Ethiopia. Geoderma 111: 85-98.

[40] Girmay, G., Singh, B. R., Nyssen, J., and Borrosen, T. (2009). Runoff and sediment-associated nutrient losses under different land uses in Tigray, Northern Ethiopia. Journal of Hydrology376: 70-80.

[41] Descheemaeker, K., Nyssen, J., Rossi, J., Poesen, J., Mitiku, H., Moeyersons, J., \& Deckers, J. (2006). Sediment deposition and pedogenesis in exclosures in the Tigray Highlands, Ethiopia. Geoderma, 132: 291-314.

[42] Abiy, T. (2008). Area closure as a strategy for land management: A case study at Kelala Dalacha enclosure in the central rift valley of Ethiopia. MSc thesis, Addis Ababa University, Ethiopia. pp107.

[43] Verdoodt, A., Mureithi, S. M., Ye, L., and Ranst, E. V. (2009). Chronosequence analysis of two enclosure management strategies in degraded rangeland of semi-arid Kenya. Agric. Ecosyst. Environ. 129: 332-339.

[44] Zenebe, G. (2007). Household fuel consumption and resource use in rural-urban Ethiopia. Ph. D. Dissertation. Wageningen University. The Netherlands. ISBN: 978-90-8504-745-2.

[45] Mulugeta, L., Karltun, E., and Olsson, M. (2005). Soil organic matter dynamics after deforestation along a farm field chronosequence in southern highlands of Ethiopia. Agric. Ecosyst. Environ. 109: 9-19.

[46] Dereje, A., Oba, G., Weladji, R. B., and Colman, J. E. (2003). An assessment of restoration of biodiversity in degraded high mountain grazing lands in Northern Ethiopia. Land Degrad. Develop.14: 25-38.

[47] De Koning, G. H., Veldkamp, E., and Lopez-Ulloa, M. (2003). Quantification of carbon sequestration in soils following pasture to forest conversion in northwestern Ecuador. Global Biogeochem. Cy. 17: 1-12.

[48] Capoor, K., and Amborsi, P. (2008). State and trends in the carbon market 2008, Washington DC: The World Bank.

[49] Timothy, R., Pearson, H., Brown, S., Sohngen, B., Henman, J. and Ohrel, S. (2013). Transaction costs for carbon sequestration projects in the tropical forest sector. Open access at Springerlink.com. Mitig Adapt Strateg Glob Change. DOI 10.1007/s11027-013-9469-8.

[50] Usuga, J., Toro, J., Alzate, M. and Tapias, Á. (2010). Estimation of Biomass and Carbon Stocks in Plants, Soil and Forest Floor in Different Tropical Forests. Forest Ecology and Management 260: 1906-1913. 
[51] Yitebitu, M., Zewdu, E., and Sisay, N. (2010). Ethiopian Forest Resources: Current Status and Future Management Options in View of Access to Carbon Finances. A Review: Prepared for the Ethiopian Climate Research and Networking and the United Nations Development Program (UNDP).

[52] Achard, F., Eva, H. D., Mayaux, P., Stibig, H. J. and Belward, A. (2004). Improved estimates of net carbon emissions from land cover change in the tropics for the 1990s Glob. Biogeochem. Cycles 18: 1029-1042.

[53] Anup, K. C., Bhandari, G., Joshi, G. R. and Aryal, S. (2013). Climate change mitigation potential from carbon sequestration of community forest in mid hill region of Nepal. Int. $J$. Environ. Prot. 3 (7): 33-40.

[54] Brown, S. and Lugo, A. E. (1982). The storage and production of organic matter in tropical forests and their role in the global carbon cycle. Biotropica. 14: 161-187.

[55] Lasco, R. D., Pulhin, F. B., Visco, R. G., Racelis, D. A., Guillermo, I. Q. and Sales, R. F. (2000). Carbon stocks assessment of Philippine forest ecosystems. Paper presented at the Science-Policy workshop on terrestrial carbon assessment for possible carbon trading, Bogor, pp. 28-29.

[56] Sheikh, M. A., Kumar, M., and Bussmann, R. W. (2009). Altitudinal variation in soil organic carbon stock in coniferous subtropical and broadleaf temperate forests in Garhwal Himalaya. Carbon Balanceand Management 4: 1-6.

[57] Houghton, R. A. (2005). Tropical deforestation as a source of greenhouse gas emissions. In: Moutinho, P., and Schwarzman, S. (eds.). Tropical deforestation and climate change. IPAM Instituto de Pesquisa Ambiental de Amazonia; Washington DC, USA.

[58] Asner, G. P., Anderson, C. B., Martin, R. E., Knapp, D. E., Tupayachi, R., Sinca, F. and Malhi, Y. (2014). Landscapescale changes in forest structure and functional traits along an Andes-to-Amazon elevation gradient. Biogeosciences 11: 843856.

[59] Murphy, P. G., and Lugo, A. E. (1986). Ecology of Tropical Dry Forest. Annual Review of Ecology and Systematics 17: 67-88.

[60] Bayat, T. A. (2011). Carbon stock in an Apennine beech forest. MSc. Thesis. University of Twente, Enschede, the Netherlands.

[61] Muluken, N. (2014). Carbon Stock in Adaba-Dodola Community Forest of Danaba District, West-Arsi Zone of Oromia Region, Ethiopia: An Implication for Climate Change Mitigation. MSc. Thesis. Addis Ababa University.

[62] Nesru Hassen (2015). Carbon Stocks along Altitudinal Gradient in Gera Moist Evergreen Afromontane forest, Southwest Ethiopia. MSc. Thesis. Addis Ababa University.
[63] Abel, G., Teshome, S., and Tesfaye, B. (2014). Forest Carbon Stocks in Woody Plants of Mount Zequalla Monastery and its Variation along Altitudinal Gradient: Implication of Managing Forests for Climate Change Mitigation. Science, Technology, and Arts Research Journal 3 (2): 133-141.

[64] Belay, M., Ensermu, K., and Teshome, S. (2014). Forest Carbon Stocks in Woody Plants of Arba Minch Ground Water Forest and its Variations along Environmental Gradients. Science, Technology, and Arts Research Journal 3 (2): 141147.

[65] Adugna, F., Teshome, S., and Mekuria, A. (2013). Forest carbon stocks and variations along altitudinal gradients in Egdu Forest: Implications of managing forests for climate change mitigation. Science, Technology, and Arts Resesearch Journal 2 (4): 40-46.

[66] Mesfin, S. (2011). Estimating and Mapping of Carbon Stocks based on Remote Sensing, GIS and Ground Survey in the Menagesha Suba State Forest, Ethiopia. MSc. Thesis, Addis Ababa University.

[67] Tulu Tolla (2011). Estimation of Carbon Stock in Church Forests: Implications for Managing Church for Forest Carbon Emission Reduction. MSc. Thesis. Addis Ababa University.

[68] Getu, S. (2012). Carbon Stocks in Different Pools in Natural and Plantation Forests of Chilimo, Central Highlands of Ethiopia. MSc. Thesis, Addis Ababa Univesity, Ethiopia.

[69] Mohammed, G., Teshome, S., and Satishkumar, B. (2014). Forest carbon stocks in woody plants of Tara Gedam forest: Implication for climate change mitigation. Sci. Technol. Arts Res. J. 3 (1): 101-107.

[70] Marshet, T., and Teshome, S. (2015). Carbon Stock Potentials of Woody Plant Species in Biheretsige and Central Closed Public Parks of Addis Ababa and Its Contribution to Climate Change Mitigation. Journal of Environment and Earth Science 5 (13): 2216-2224.

[71] Dagnachew, T. (2016). Carbon stock of meskele gedam forest and its contribution to climate change mitigation. Msc. Thesis, Adis Ababa University, Addis Ababa. Pp.85.

[72] Fentahun, A., Yehualashet, B., Alemayehu, K., and Teshome, S. (2017). Carbon stock of Banja forest in Banja district, Amhara region, Ethiopia: An implication for climate change mitigation, Journal of Sustainable Forestry DOI: 10.1080/10549811.2017.1332646.

[73] FAO. (1984). Agroclimatic Resource Inventory for Land use Planning. Ethiopia. Technical Report 2. AG: DP/ETH/78/003, Rome. 